\title{
Geochemical characteristics of Kirka (Sarıkaya) borate deposit, northwestern Anatolia, Turkey
}

\author{
İ $\mathrm{KOÇAK}^{1, *}$ and Ş Koç${ }^{2}$ \\ ${ }^{1}$ Department of Geological Engineering, Bozok University, 66100, Atatürk Way, Yozgat, Turkiye. \\ ${ }^{2}$ Department of Geological Engineering, Ankara University, 06100, Tandogan, Ankara, Turkiye. \\ *Corresponding author.e-mail: ismail.kocak@bozok.edu.tr
}

The Kırka borate deposit was deposited in a Miocene lacustrine basin which is closely associated with volcanic activity which lasted from Paleogene to the beginning of Quaternary. Borate mineralization alternates with claystone, mudstone, tuff and fine-layered limestone and mostly shows a lenticular structure. The mineral paragenesis is composed of borax, tincalconite, ulexite, kurnakovite, probertite, tunellite, colemanite, dolomite, smectite group minerals, illite and some firstly reported minerals for the Kırka deposit including hydrochloroborite, brianroulstonite, hilgardite-4M and searlesite minerals. In comparison to average values of earth crust, concentrations of $\mathrm{Cs}, \mathrm{Sr}, \mathrm{Li}, \mathrm{As}$ and Se were significantly enriched with respective rates of 21, 15, 14, 3 and 188 folds. Regarding KY, KS1 and KS2 locations, there are differences in both element abundances and their geochemical tendencies which are attributed to variations in discharge regime and physico-chemical conditions of the depositional environment. Independent behaviour of $\mathrm{B}_{2} \mathrm{O}_{3}$ might indicate that boron is not associated with clays and carbonates and, therefore, most part of boron must be derived from volcanic activity (hydrothermal solutions, gases). REE data indicate that the Kırka borate deposit was formed in a sedimentary environment where highly alkaline (high $\mathrm{pH}$ ) hydrothermal solutions also took part in borate precipitation process.

\section{Introduction}

Kırka (Eskişehir), Kestelek (Bursa), Bigadiç (Balıkesir) and Emet (Kütahya) borate deposits in western Anatolia (figure 1a) comprise about $72 \%$ of world borate reserve. This work is related to Kirka borate deposit. Previous studies proposed that borate deposits in Turkey, including Kirka, were formed in lacustrine environments in association with volcanism started in Paleogene and continued to the beginning of Quaternary (Helke 1955; Özpeker 1969; Baysal 1972, 1973, 1974; Baysal and Ataman 1975; İnan 1975; Özpeker and İnan 1978; Ataman and Baysal 1978; Sunder 1980; Helvacı 1983; Yalçın 1988; Yalçın et al. 1989; Akyol and Akgün 1990; Yalçın and Baysal
1991; Palmer and Helvaci 1995, 1997; Floyd et al. 1998; Helvacı and Alonso 2000; Helvacı 2001, 2003; Helvaci and Orti 2004; Helvaci et al. 2004).

Various minerals are found in borate-zone in the Kırka deposit. Minerals display a mineralogical zonation consisting of $\mathrm{Na}, \mathrm{Na}-\mathrm{Ca}$ and $\mathrm{Ca}$-borates including borax, kernite, tincalconite, ulexite, inyoite, meyerhofferite, colemanite, inderborite, hydroboracite, kurnakovite, pandermite, inderite and tunellite (Sunder 1980; Yalcin 1988; Yalçın and Baysal 1991; Palmer and Helvacı 1995). Among the deposits of Borate in Turkey, Kırka borate deposit is the only deposit that Na-borate minerals are dominant (Helvaci 2003). In these studies, only geology and borate mineral types in the deposit

Keywords. Kırka; borate; mineralogy; geochemistry; REE. 


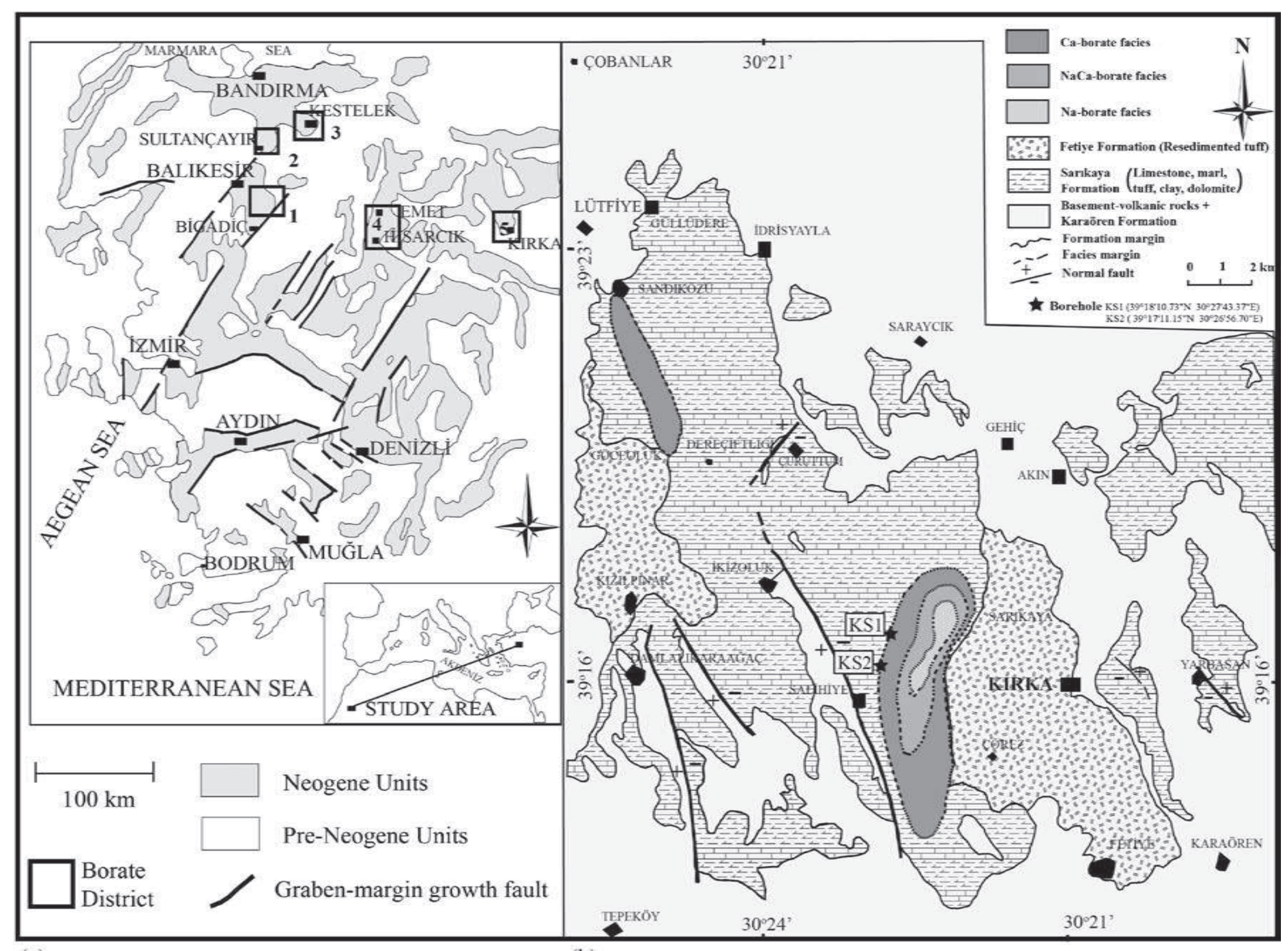

(a)

(b)

Figure 1. (a) Distribution of borate deposits (modified from Helvacı and Orti 2004) and (b) geology map of Kırka borate deposit and surrounding parts (Yalçın and Baysal 1991). 
were investigated. However, major and trace element contents of the Kirka borates have not been studied before.

Major and trace element chemistry provide important information on the origin of ore deposits. Likewise, several trace elements may be more important than the major elements in a deposit. Also, it should not be ruled out that some elements that are not recently used or difficult to be exploited due to economic and technical conditions might be processed with improving opportunities. Similar studies were also carried out in the Kestelek (Koç et al. 2008a, b, c; Koçak and Koç 2011) and Bigadiç borate deposits (Koçak and Koç 2009, 2011, 2012).

Major and trace element contents of borate minerals, their enrichment levels and assessment by means of environmental conditions were first mentioned in Koç et al. (2008a, b, c); Koçak and $\operatorname{Koç}(2009,2011,2012)$ and it was found that Se, $\mathrm{Sr}, \mathrm{As}, \mathrm{Cs}, \mathrm{Li}, \mathrm{Sb}$ and Mo were enriched with respect to the average earth crust and andesite concentrations.

In the present work, major and trace element contents of the Kirka borates are studied. In this respect, recharge and depositional environment characteristics which were effective during the borate formation stage are evaluated with the use of geochemical data. For this aim, primarily major and trace element (including REE) concentrations of borate minerals and element enrichment levels were investigated. Based on inter-correlations, genetic affinity of elements, REE abundances and anomaly values, depositional environment conditions are discussed.

\section{Materials and methods}

Borate mineral samples collected from the Kırka borate deposit are the material of this work. Samples were taken from open pit surfaces and boreholes drilled by the Etibank Kırka Borate Exploitation Management which is nearly located at the center of borate basin. The borehole KS1 (BMK $2003 / 14$ ) is at northwest of open pit, while borehole KS2 (BMK 2002/27) is at southwestern part. Surface samples (KY) were collected from certain levels showing variations from bottom to upper part of the Kırka open pit. Representative samples were collected from various parts of the basin to investigate major and trace element concentrations in borate minerals in central and marginal parts.

A total of 47 samples were taken; 8 (KS1) and 13 (KS2) from boreholes and 26 (KY) samples from the surface. Before the geochemical analysis, samples were cleaned with pressurized air and then washed to remove the clay particles.
In mineralogical studies, microscope, X-ray diffractometer (XRD) and confocal Raman method were used. XRD determinations of the samples were performed by X-ray diffraction (XRD) at the Turkish Petroleum Corporation (TPAO) laboratories in Ankara. A Rigaku-D model Max 2200 Ultima/Pc X-ray diffractometer with a $\mathrm{Cu}$ target was used in the analyses with $40 \mathrm{Kv}, 20 \mathrm{~mA}$, $1,54059 \AA(\mathrm{CuK} \alpha 1)$ wave length and a scanning speed of $2^{\circ} 2 \theta / \mathrm{min}$. The Raman method was applied with Olympus BX41 model confocal Raman Spectrometer device at Petrography Research and Application Laboratory, Geology Department, Ankara University.

Chemical analysis was conducted at ACME (Canada) and Laboratories of the Eti Mine Works General Management. Major oxides were analyzed with Inductively-Coupled Plasma-Emission Spectrometry (ICP-ES) and trace and REE elements were determined with Inductively-Coupled Plasma-Mass Spectrometry (ICP-MS) method.

$\mathrm{B}_{2} \mathrm{O}_{3}$ analysis was performed with volumetric method at the Laboratories of the Eti Mine Works General Management.

\section{Geologic setting}

There are several studies concerning geology of the region stating that borate minerals were deposited in playa lakes within the Neogene units (Inan 1975; Sunder 1980; Yalçın 1988; Yalçın and Baysal 1991; Helvaci and Orti 2004).

Around the Kirka basin, pre-Miocene basement rocks (metamorphics consist of crystallized limestone, chloritie schist, metasandstone in Paleozoic; ophiolites in Cretaceous and carbonates in Eocene) and Neogene volcanic and sedimentary units are exposed. The Neogene units are represented by İdrisyayla volcanites (andesite, rhyolite and volcanic breccia), Karaören Formation (zeolitebearing tuffs), Sarıkaya Formation, Türkmendağ 1 Basalt and Fetiye Formation (resedimented tuff) (figure 1b).

According to Yalçın and Baysal (1991), middleupper Miocene Sarıkaya formation which hosts the borate deposits has a thickness of 150-300 m. The formation starts with $20-50 \mathrm{~m}$ thickened, massive thick-bedded limestones in travertine-like fibrous structure, alternating with claystone and tuff bands in centimeter scale and continues with 10-40 m thickened, thin-bedded dolomitic limestone. Laminated claystone/marl-dolomite level overlying the dolomitic limestone has a thickness of 5-40 m. Clayey-carbonaceous borate level of 20-160 m thickness is interlayered with tuffs in centimeter scale and contains altered, fibrous pumice particles. Above this zone, laminated claystone/ 


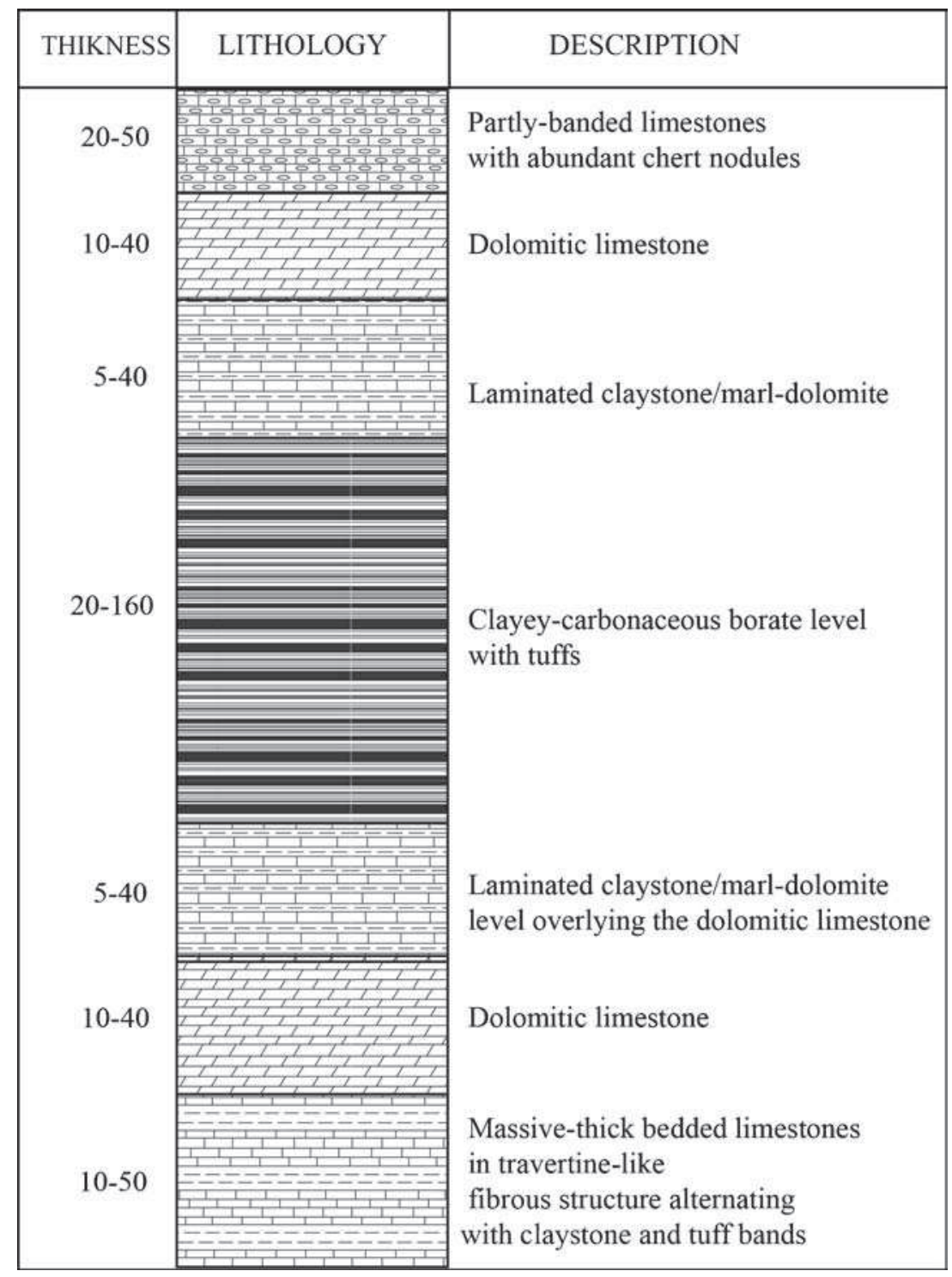

Figure 2. Cross-section of the Sarkkaya Formation.

marl-dolomite alternation has a thickness of 5$40 \mathrm{~m}$. This level is represented by hundreds of syn-sedimentary normal faults with slip rates in the range of milimeter to meter, interlayer folds and wrinkles or dislocations and load/slump structures. Upper part of formation is comprised by $10-$ $40 \mathrm{~m}$ thickened dolomitic limestones and 20-50 m thickened, fibrous, partly banded limestones with abundant chert nodules (figure 2).

\section{Analytical data and discussion}

\subsection{Mineralogy of borate deposit}

Borate minerals in the Kirka deposit are borax, tincalconite, ulexite, kurnakovite, probertite, tunellite and colemanite and some firstly reported minerals for the Kırka deposit including hydrochloroborite, brianroulstonite, hilgardite-4M and searlesite minerals (figure 3 ). In the assemblage, dolomite and smectite group minerals and illite are also found.

In the exploited part of deposit (KY), $\mathrm{Na}$ and Mg-borates are dominant, while western section (KS1 and KS2) is comprised by Ca-borates. In $\mathrm{KY}$ samples, deposition from bottom to the top is represented by Na-borate, NaCa-borate, Naborate, $\mathrm{Mg}$-borate + NaCa-borate, NaCa-borate, $\mathrm{Mg}$-borate + NaCa-borate and Ca-borate + Srborate. The order of minerals in KS1 is NaCaborate, Na-borate and $\mathrm{NaCa}$-borate and that in KS2 is NaCa-borate, Ca-borate, NaCa-borate and Ca-borate.

Borax showing brecciated, banded and glassy textures is the main mineral in the Na-borate zone. The NaCa-borate zone composing of ulexite is just above the Na-borate zone. Ulexite is accompanied by kurnakovite, tunellite and probertite. Ulexite is 

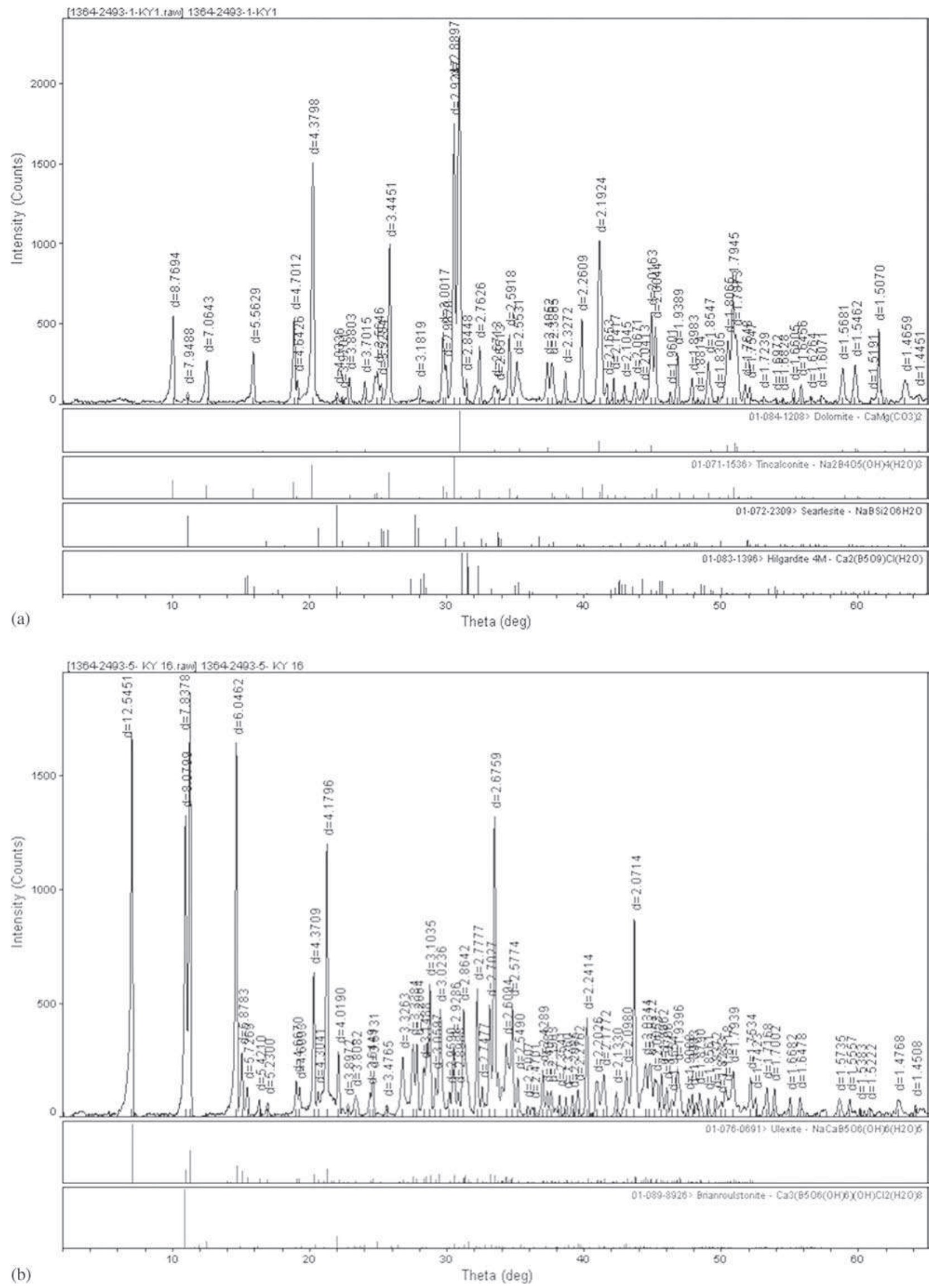

Figure 3. XRD diffractogram of first reported minerals for the Kırka: (a) hilgardite-4M and searlesite; (b) brianroulstonite; and (c) hydrochloroborite. 


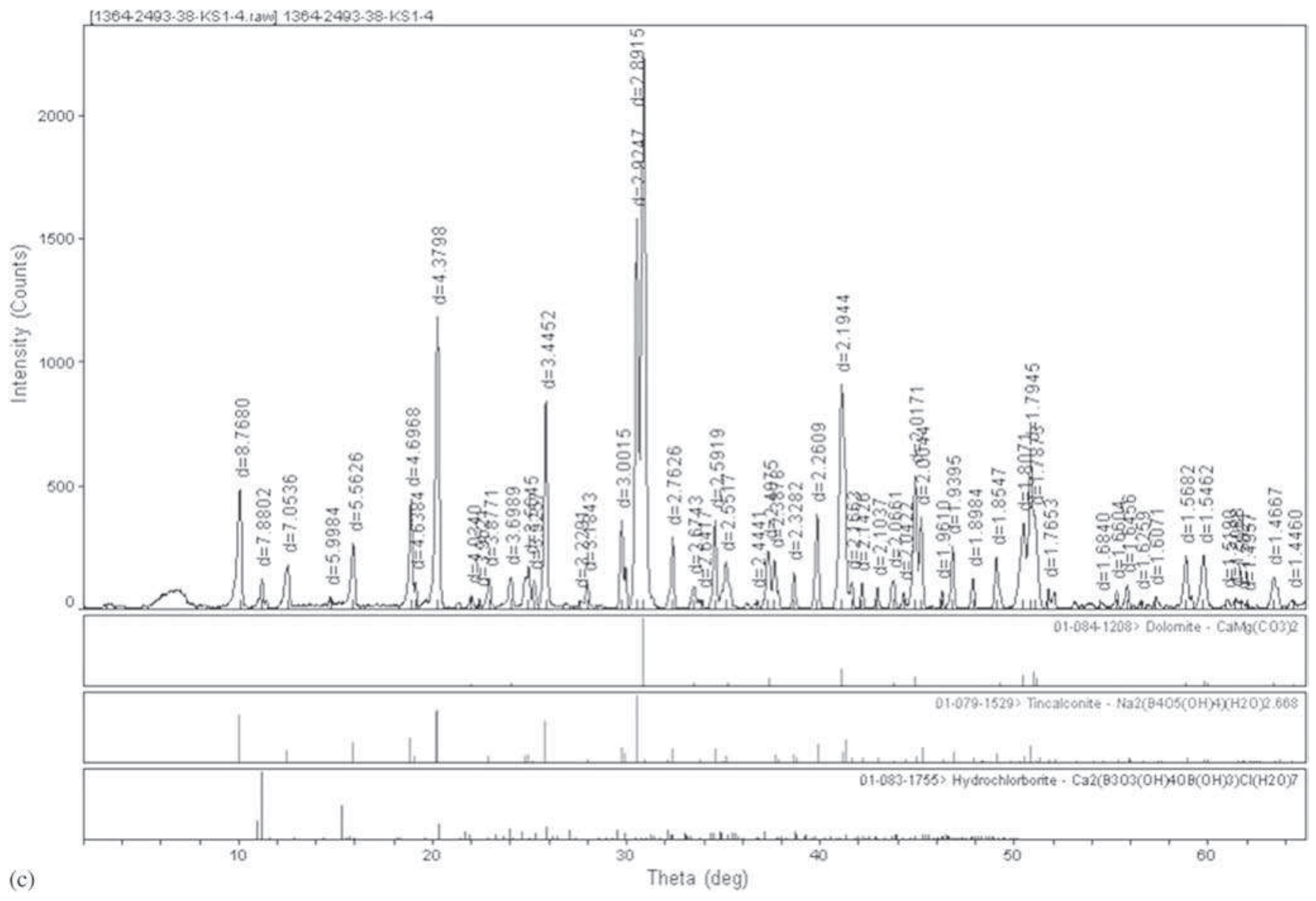

Figure 3. (Continued.)

massive, nodular and occurs as thin veins. Kurnakovite in NaCa-borate zone occurs in clay as prismatic single crystals of $1-20 \mathrm{~cm}$ size or crystal groups. Tunellites in platy texture and transparent appearance is found together with ulexite. Probertite is massive and transparent. Ca-borate zone comprises the upper-most part of borate deposition. Colemanite which is the main mineral occurs as transparent layers.

\subsection{Geochemical properties of Kirka deposit}

In this study, major, trace and rare earth element variations in a total of 47 samples from $\mathrm{KY}$, KS1 and KS2 are examined. Element abundances and correlations are used to discuss deposition evolution of Kirka borates.

\subsubsection{Major element abundances in Kırka borate deposit}

The major element abundances, concentration ranges, their average values and average concentrations of earth crust (ECA), andesite (AA) and freshwater
(FWA) are given in table 1. Concentrations of all major elements are increased with respect to FWA. The $\mathrm{B}_{2} \mathrm{O}_{3}$ concentration in all samples is in the range of $26.42-44.89 \mathrm{wt} \%$ with an average of 37.3 wt\%. The order of abundance of other elements with respect to average values is $\mathrm{Na}$ $(7.27)>\mathrm{Ca}(5.84)>\mathrm{Mg}(2.35)>\mathrm{Si}(1.30)>\mathrm{K}$ $(0.14)>\mathrm{Al}(0.12)>\mathrm{Fe}(0.09)($ in $\%)$. When these values are compared to ECA and $\mathrm{AA}, \mathrm{Na}$ content is enriched by 3.03-2.42 folds, $\mathrm{Ca}$ and $\mathrm{Mg}$ also slightly enriched while concentration of others ( $\mathrm{Si}$, $\mathrm{K}, \mathrm{Al}$ and $\mathrm{Fe}$ ) are significantly depleted (17-71 folds) (figure 4).

Comparison of element concentrations from $\mathrm{KY}$, KS1 and KS2 samples (table 1) reveals different results for different parts of the depositional environment. For example, high $\mathrm{Na}$ and $\mathrm{Mg}$ concentrations are found in $\mathrm{KY}$ area indicating presence of $\mathrm{Na}-\mathrm{Mg}$ borates. However, Ca concentrations in KS1 and KS2 samples are higher than those of $\mathrm{KY}$. This might show westward increase of Caborates in Kurka borate deposit. $\mathrm{Si}, \mathrm{K}, \mathrm{Al}$ and Fe concentrations in samples are lower than those of ECA and AA and found to be higher in $\mathrm{KY}$ area. 
Table 1. Major element contents of Kirka samples (\%). (1) Krauskopf (1989), (2) Schroll (1975), (3) Abollino et al. (2004) (does not contain B $\left.2 O_{3}\right)$.

\begin{tabular}{|c|c|c|c|c|c|c|c|c|c|c|c|c|c|}
\hline Sample & Depth (m) & $\mathrm{B}_{2} \mathrm{O}_{3}(\%)$ & Si $(\%)$ & $\mathrm{Al}(\%)$ & $\mathrm{Fe}(\%)$ & $\operatorname{Mg}(\%)$ & $\mathrm{Ca}(\%)$ & $\mathrm{Na}(\%)$ & K $(\%)$ & TOT/C (\%) & TOT/S (\%) & LOI $(\%)$ & $\operatorname{Sum}(\%)$ \\
\hline KY26 & 1096.0 & 42.24 & 0.34 & 0.02 & $<0.03$ & 1.06 & 7.84 & 3.82 & $<0.01$ & 3.61 & $<0.02$ & N.A. & 13.07 \\
\hline KY25 & 1094.5 & 37.01 & 0.97 & 0.18 & 0.04 & 5.26 & 4.22 & 2.42 & 0.12 & 2.47 & $<0.02$ & N.A. & 13.20 \\
\hline KY24 & 1094.0 & 35.92 & 0.52 & 0.04 & $<0.03$ & 8.20 & 1.24 & 0.51 & 0.03 & 3.43 & $<0.02$ & N.A. & 10.54 \\
\hline KY23 & 1093.0 & 35.43 & 2.26 & 0.20 & 0.08 & 3.73 & 6.77 & 3.89 & 0.20 & 0.52 & $<0.02$ & N.A. & 17.12 \\
\hline KY22 & 1092.0 & 39.21 & 0.72 & 0.01 & $<0.03$ & 3.98 & 6.06 & 3.46 & $<0.01$ & 0.32 & $<0.02$ & N.A. & 14.23 \\
\hline KY21 & 1082.0 & 34.02 & 0.79 & 0.07 & 0.03 & 9.19 & 1.16 & 0.14 & 0.02 & 0.31 & $<0.02$ & N.A. & 11.42 \\
\hline KY20 & 1081.0 & 33.25 & 2.79 & 0.09 & $<0.03$ & 3.03 & 9.58 & 4.75 & 0.05 & 1.36 & $<0.02$ & N.A. & 20.28 \\
\hline KY19 & 1080.0 & 32.73 & 1.65 & 0.25 & 0.09 & 7.84 & 2.90 & 1.14 & 0.20 & 0.04 & $<0.02$ & N.A. & 14.07 \\
\hline KY18 & 1079.0 & 36.46 & 2.23 & 0.21 & 0.08 & 1.83 & 8.97 & 4.95 & 0.23 & 0.16 & $<0.02$ & N.A. & 18.50 \\
\hline KY17 & 1078.0 & 37.78 & 0.93 & 0.10 & 0.03 & 4.24 & 0.99 & 6.48 & 0.06 & 0.25 & $<0.02$ & N.A. & 12.83 \\
\hline KY16 & 1077.0 & 37.28 & 3.01 & 0.62 & 0.22 & 0.85 & 8.38 & 5.03 & 0.78 & 2.16 & 0.03 & N.A. & 18.90 \\
\hline KY15 & 1076.0 & 40.96 & 0.06 & 0.01 & $<0.03$ & 0.04 & 0.04 & 12.36 & $<0.01$ & 0.33 & $<0.02$ & N.A. & 12.50 \\
\hline KY14 & 1075.0 & 37.58 & 0.54 & 0.02 & $<0.03$ & 0.90 & 1.04 & 11.93 & 0.02 & 0.48 & $<0.02$ & N.A. & 14.45 \\
\hline KY13 & 1071.0 & 41.83 & 0.23 & 0.02 & $<0.03$ & 0.78 & 0.25 & 13.05 & 0.01 & 0.81 & $<0.02$ & N.A. & 14.34 \\
\hline KY12 & 1070.0 & 39.50 & 0.89 & 0.18 & 0.06 & 0.54 & 0.58 & 12.06 & 0.17 & 0.04 & $<0.02$ & N.A. & 14.47 \\
\hline KY11 & 1062.0 & 34.36 & 2.02 & 0.15 & 0.04 & 2.24 & 3.27 & 10.78 & 0.17 & 0.16 & $<0.02$ & N.A. & 18.68 \\
\hline KY10 & 1061.5 & 39.46 & 0.51 & 0.09 & 0.03 & 0.39 & 0.39 & 11.77 & 0.10 & 0.11 & $<0.02$ & N.A. & 13.28 \\
\hline KY9 & 1060.5 & 38.85 & 2.42 & 0.60 & 0.23 & 0.60 & 0.53 & 11.97 & 0.47 & 1.09 & $<0.02$ & N.A. & 16.81 \\
\hline KY8 & 1060.0 & 36.35 & 3.13 & 0.87 & 0.14 & 0.27 & 0.09 & 10.97 & 1.19 & 1.26 & $<0.02$ & N.A. & 16.66 \\
\hline KY7 & 1057.0 & 37.13 & 1.21 & 0.03 & $<0.03$ & 2.00 & 2.22 & 11.15 & 0.02 & 1.94 & $<0.02$ & N.A. & 16.63 \\
\hline KY6 & 1056.0 & 40.86 & 0.35 & 0.05 & $<0.03$ & 0.51 & 0.34 & 11.97 & 0.02 & 0.79 & $<0.02$ & N.A. & 13.25 \\
\hline KY5 & 1055.0 & 39.37 & 0.79 & 0.19 & 0.06 & 0.49 & 0.53 & 12.10 & 0.20 & 0.18 & $<0.02$ & N.A. & 14.34 \\
\hline KY4 & 1054.0 & 39.91 & 0.38 & 0.04 & $<0.03$ & 0.65 & 0.74 & 12.15 & 0.02 & 0.82 & $<0.02$ & N.A. & 13.98 \\
\hline KY3 & 1053.0 & 28.71 & 2.10 & 0.06 & $<0.03$ & 3.55 & 5.78 & 9.30 & 0.06 & 0.34 & $<0.02$ & N.A. & 20.85 \\
\hline KY2 & 1052.0 & 33.42 & 1.99 & 0.03 & $<0.03$ & 2.30 & 4.32 & 10.52 & 0.05 & 0.35 & $<0.02$ & N.A. & 19.22 \\
\hline KY1 & 1050.0 & 28.03 & 2.54 & 0.04 & $<0.03$ & 4.31 & 5.07 & 8.85 & 0.06 & 0.88 & $<0.02$ & N.A. & 20.87 \\
\hline Average of KY samples & & 36.83 & 1.36 & 0.16 & 0.09 & 2.65 & 3.20 & 7.98 & 0.19 & 0.93 & 0.03 & N.A. & 15.62 \\
\hline KS1-1 & 90 & 41.10 & 0.36 & 0.01 & $<0.03$ & 0.39 & 9.88 & 5.47 & $<0.01$ & 0.3 & $<0.02$ & N.A. & 16.10 \\
\hline KS1-2 & 105 & 43.97 & 0.50 & 0.02 & $<0.03$ & 0.48 & 3.87 & 11.54 & 0.02 & 0.36 & $<0.02$ & N.A. & 16.42 \\
\hline KS1-3 & 108.5 & 40.79 & 1.27 & 0.04 & $<0.03$ & 2.09 & 2.30 & 13.56 & 0.04 & 1.58 & $<0.02$ & N.A. & 19.30 \\
\hline KS1-4 & 110 & 27.51 & 2.74 & 0.09 & $<0.03$ & 5.42 & 7.57 & 9.17 & 0.10 & 4.77 & $<0.02$ & N.A. & 25.09 \\
\hline KS1-5 & 116 & 44.04 & 0.77 & 0.04 & $<0.03$ & 0.72 & 3.04 & 12.70 & 0.04 & 0.54 & $<0.02$ & N.A. & 17.31 \\
\hline KS1-6 & 139.3 & 38.08 & 1.00 & 0.02 & $<0.03$ & 1.42 & 10.48 & 5.09 & 0.02 & 1 & $<0.02$ & N.A. & 18.03 \\
\hline KS1-7 & 142.5 & 37.56 & 1.07 & 0.02 & $<0.03$ & 1.51 & 10.33 & 4.99 & 0.02 & 1.08 & $<0.02$ & N.A. & 17.94 \\
\hline $\mathrm{KS} 1-8$ & 145.3 & 26.56 & 4.39 & 0.33 & $<0.03$ & 4.85 & 10.94 & 3.56 & 0.42 & 3.31 & $<0.02$ & N.A. & 24.50 \\
\hline Average of KS1 samples & & 37.45 & 1.51 & 0.07 & - & 2.11 & 7.30 & 8.26 & 0.10 & 1.62 & $<0.02$ & N.A. & 19.35 \\
\hline
\end{tabular}


Table 1. (Continued.)

\begin{tabular}{|c|c|c|c|c|c|c|c|c|c|c|c|c|c|}
\hline Sample & Depth $(\mathrm{m})$ & $\mathrm{B}_{2} \mathrm{O}_{3}(\%)$ & Si $(\%)$ & $\mathrm{Al}(\%)$ & $\mathrm{Fe}(\%)$ & $\mathrm{Mg}(\%)$ & $\mathrm{Ca}(\%)$ & $\mathrm{Na}(\%)$ & $\mathrm{K}(\%)$ & $\mathrm{TOT} / \mathrm{C}(\%)$ & TOT/S (\%) & LOI $(\%)$ & Sum $(\%)$ \\
\hline KS2-1 & 163.1 & 43.74 & 1.06 & 0.02 & $<0.03$ & 1.62 & 17.08 & 0.01 & 0.01 & 1 & $<0.02$ & N.A. & 19.80 \\
\hline KS2-2 & 167 & 35.10 & 0.85 & 0.01 & $<0.03$ & 2.37 & 10.86 & 4.78 & 0.02 & 1.95 & $<0.02$ & N.A. & 18.88 \\
\hline KS2-3 & 175 & 39.21 & 0.48 & 0.03 & $<0.03$ & 1.83 & 8.69 & 5.25 & 0.02 & 0.85 & $<0.02$ & N.A. & 16.31 \\
\hline $\mathrm{KS} 2-4$ & 200 & 42.45 & 0.50 & 0.02 & $<0.03$ & 2.03 & 3.15 & 11.79 & 0.02 & 1.05 & $<0.02$ & N.A. & 17.50 \\
\hline $\mathrm{KS} 2-5$ & 210 & 44.89 & 0.43 & 0.08 & $<0.03$ & 0.48 & 3.22 & 12.33 & 0.05 & 0.22 & $<0.02$ & N.A. & 16.60 \\
\hline $\mathrm{KS} 2-6$ & 225 & 38.55 & 0.96 & 0.04 & $<0.03$ & 1.22 & 10.03 & 5.25 & 0.03 & 0.81 & $<0.02$ & N.A. & 17.53 \\
\hline $\mathrm{KS} 2-7$ & 235 & 40.02 & 0.91 & 0.24 & $<0.03$ & 0.66 & 9.08 & 5.45 & 0.18 & 0.34 & $<0.02$ & N.A. & 16.52 \\
\hline $\mathrm{KS} 2-8$ & 247 & 40.73 & 0.85 & 0.15 & $<0.03$ & 0.34 & 9.33 & 5.62 & 0.15 & 0.09 & $<0.02$ & N.A. & 16.44 \\
\hline KS2-9 & 255 & 31.37 & 1.60 & 0.20 & $<0.03$ & 3.10 & 11.31 & 4.48 & 0.21 & 2.58 & $<0.02$ & N.A. & 20.90 \\
\hline $\mathrm{KS} 2-10$ & 265 & 42.19 & 1.29 & 0.11 & $<0.03$ & 1.92 & 16.92 & 0.15 & 0.10 & 1.49 & $<0.02$ & N.A. & 20.48 \\
\hline KS2-11 & 295 & 29.50 & 1.04 & 0.01 & $<0.03$ & 4.25 & 12.11 & 3.92 & 0.02 & 4.01 & $<0.02$ & N.A. & 21.35 \\
\hline KS2-12 & 300 & 41.70 & 0.40 & 0.04 & $<0.03$ & 0.21 & 9.71 & 5.47 & 0.05 & 0.16 & $<0.02$ & N.A. & 15.88 \\
\hline $\mathrm{KS} 2-13$ & 312 & 26.42 & 3.09 & 0.18 & $<0.03$ & 4.91 & 11.24 & 3.56 & 0.24 & 3.79 & $<0.02$ & N.A. & 23.23 \\
\hline Average of KS2 samples & & 38.14 & 1.03 & 0.09 & - & 1.92 & 10.21 & 5.24 & 0.08 & 1.41 & $<0.02$ & N.A. & 18.57 \\
\hline Average of all samples & & 37.30 & 1.30 & 0.12 & 0.09 & 2.35 & 5.84 & 7.27 & 0.14 & 1.18 & 0.03 & N.A. & 17.11 \\
\hline Standard deviation & & 4.84 & 0.98 & 0.17 & 0.07 & 2.22 & 4.64 & 4.20 & 0.22 & 1.22 & - & N.A. & 12.49 \\
\hline Various rates & & $\begin{array}{c}26.42- \\
44.89\end{array}$ & $\begin{array}{c}0.06- \\
4.39\end{array}$ & $\begin{array}{c}0.01- \\
0.87\end{array}$ & $\begin{array}{c}<0.03- \\
0.23\end{array}$ & $\begin{array}{c}0.04- \\
9.19\end{array}$ & $\begin{array}{l}0.04- \\
17.08\end{array}$ & $\begin{array}{l}0.01- \\
13.56\end{array}$ & $\begin{array}{c}<0.01- \\
1.19\end{array}$ & $\begin{array}{c}0.04- \\
4.77\end{array}$ & $\begin{array}{c}<0.02- \\
0.03\end{array}$ & N.A. & $\begin{array}{c}16.91- \\
38.76\end{array}$ \\
\hline Average (earth crust) (1) & & 0.0010 & 28.20 & 8.10 & 5.40 & 2.30 & 4.10 & 2.40 & 2.10 & - & - & - & - \\
\hline Average (Andesite) (2) & & 0.0015 & 26.00 & 8.85 & 5.85 & 2.18 & 4.65 & 3.00 & 2.30 & - & - & - & - \\
\hline Average (freshwaters) $(3) * 10^{-4}$ & & 0.01 & 5.33 & $<30 \cdot 10^{-3}$ & $<30 \cdot 10^{-3}$ & $\begin{array}{c}0.8-15.07 \\
\quad 3.64\end{array}$ & $\begin{array}{c}1.8-49.29 \\
13.22\end{array}$ & $\begin{array}{c}1.15- \\
36.78 ; 5.28\end{array}$ & $\begin{array}{c}0.51- \\
3.9 ; 12.9\end{array}$ & - & - & - & - \\
\hline
\end{tabular}




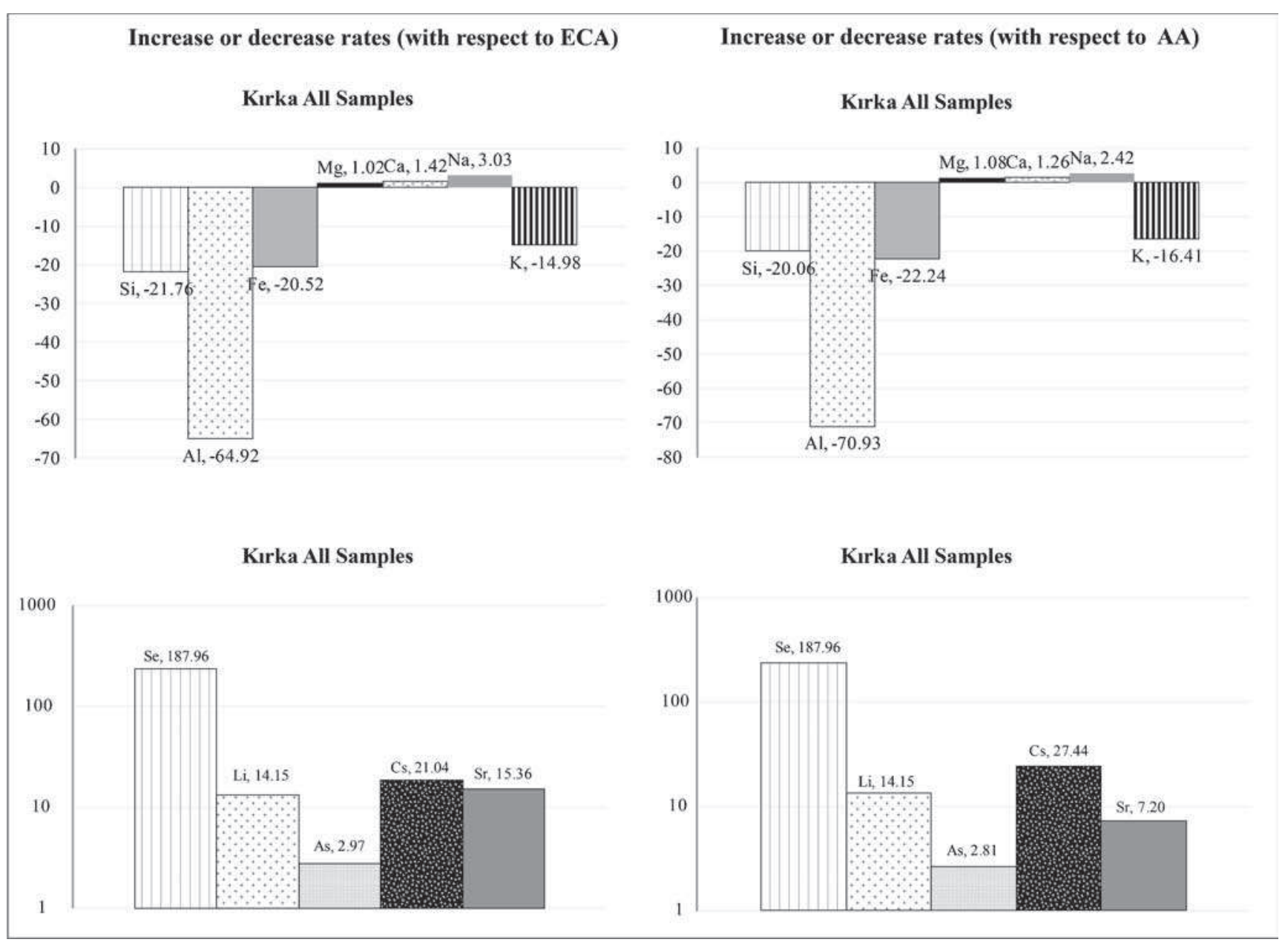

Figure 4. Bar diagrams of increase/decrease rates of elements of the Kirka.

\subsubsection{Trace element abundances in Kirka borate deposit}

Like in major elements, concentrations of trace elements (table 2) are also considerably increased with respect to FWA. However, concentrations of only five elements are increased, while others are decreased with respect to ECA and AA. The minimum-maximum concentrations (in $\mathrm{ppm}$ ) of these elements are Se $(<0.50-47.40)$, Li $(45.20-$ 791.80), As $(<0.50-23.90)$, Cs (1.80-962.40) and $\mathrm{Sr}$ (22.60-50400.00). The difference between these values is large indicating that the amount of material transported to the environment is quite variable. Average concentrations and approximate increase rate (with respect to ECA) of these elements are Se (9.40 ppm - 187.96 folds), Li (282.92 ppm - 14.15 folds), Sr (5760.73 ppm - 15.36 folds), As (5.34 ppm - 2.97 folds) and Cs (1.80 ppm - 21.04 folds) (figure 4). The abundances, the increased concentrations of elements and minimum-maximum concentrations are similar for three different sampling sites (KY, KS1 and KS2).
Comparison of major and trace element contents of two other borate deposits in western Turkey yields similar results. For example $\mathrm{Se}, \mathrm{Li}, \mathrm{Cs}, \mathrm{Sb}$, Mo, As, Sr in the Kestelek deposit (Koç et al. 2008a, b, c; Koçak and Koç 2011) and Se, Li, Mo, $\mathrm{Sb}, \mathrm{As}, \mathrm{Sr}$ in the Bigadiç deposit (Koçak and Koç 2012) are found to be enriched with respect to ECA and AA. Regarding the degree of enrichment of trace elements, the Kırka, Kestelek and Bigadiç deposits resemble each other. Particularly, Se, Li, $\mathrm{Sr}$ and As are found to be enriched in each of these deposits. Only differences are Mo-Sb enrichment in Kestelek and Cs enrichment in Kestelek and Kırka.

The previous studies indicate volcanism in the region (Palmer and Helvaci 1995; Floyd et al. 1998; Helvaci and Orti 2004). These volcanic processes related to epithermal system have provided the participation of some elements into the environment. It is known that Se and As are associated with volcanism and epithermal systems and Cs and $\mathrm{Sr}$ are related to volatile-rich solutions formed after the solidification of magma. Lithium may replace aluminum in muscovite and other aluminosilicates 
(Elkin and Margrave 1968; Bürküt 1977; Akçay 2002; Halilova 2004). Therefore, in the study area, (a) Miocene volcanism and related hydrothermal solutions and volatiles, as well as, (b) clays transported from terrestrial regions, might be the source of these elements. This will be discussed in detail in the next section of correlation analysis.

\subsection{Correlation analysis}

Correlations between elements in borate samples yield some important information regarding formation conditions. Data given in table 3 show that there are strong-very strong positive correlations between $\mathrm{Si}, \mathrm{Al}, \mathrm{Fe}$ and $\mathrm{K}$. Regarding trace elements, $\mathrm{Cs}, \mathrm{Nb}, \mathrm{Rb}, \mathrm{Zr}, \mathrm{Ni}, \mathrm{Pb}$, As and REE also positively correlated with each other and major elements as well. Si shows strong positive correlation with $\mathrm{Li}$ and Mo, which are not included to the above-mentioned trace element group, and weak positive correlation with $\mathrm{Mg}, \mathrm{Ca}$ and $\mathrm{U}$. This indicates that Si may be derived from two different sources. Considering that $\mathrm{Si}$ together with $\mathrm{Al}$ is resistant to chemical alteration and indicative of detrital origin (Boggs 2009; Fu et al. 2011), it can be stated that they are transported from terrestrial environment to the lake basin in association with clays. If this is the case, $\mathrm{Cs}, \mathrm{Nb}, \mathrm{Rb}, \mathrm{Zr}, \mathrm{Ni}, \mathrm{Pb}, \mathrm{As}$ and REE should have also been transported by the clays. Elements can be transported as absorption on the surface of clay and easily be released in the borate depositional environment and thus become a part of the borate crystal structure. Furthermore, it is possible to release the depositional environment appropriate conditions in the clay structure (Krauskopf 1989). Some part of Si might be brought to the lacustrine environment in the form of silicic acid as an alteration product of silicates (Krauskopf 1989).

$\mathrm{Mg}$ and $\mathrm{Ca}$ display different behaviours. $\mathrm{Mg}$ is weakly positively correlated with $\mathrm{Si}(0.29)$ and negatively correlated with $\mathrm{Na}(-0.57)$. Ca is very positively correlated with $\mathrm{Se}$ and strongly negatively correlated with $\mathrm{Na}(-0.67)$. Ca is also weakly positively correlated with Sr, U and Mo. The lack of relation between detrital group and $\mathrm{Ca}-\mathrm{Mg}$ pair might indicate the later elements differ in transport mechanism to the depositional site compared to the former. Weak positive correlation with Si shows that some part of $\mathrm{Mg}$ has a silicate origin.

$\mathrm{Na}$ is the only major element which shows positive correlation (slightly weak) with $\mathrm{B}_{2} \mathrm{O}_{3}(0.27)$. Regarding trace elements, sodium shows strong positive correlation only with $\mathrm{Cu}$. In addition to negative correlations with $\mathrm{Ca}$ and $\mathrm{Mg}$, Na generally shows very weak negative correlations with other major and trace elements.
$\mathrm{B}_{2} \mathrm{O}_{3}$ is strongly negatively correlated with $\mathrm{Si}$, $\mathrm{Mg}$ and $\mathrm{Li}$, very weakly correlated with $\mathrm{Ca}$ and $\mathrm{K}$, weakly correlated with $\mathrm{U}$ and Mo and very weakly positively correlated with Na. These correlations reveal that $\mathrm{Na}$ and $\mathrm{B}_{2} \mathrm{O}_{3}$ are not associated with clays and carbonates and in fact they are derived from hydrothermal solutions and exhalations.

TOT/C (total carbon) is strongly correlated with none of the elements. It shows weak positive correlation with $\mathrm{Si}, \mathrm{Mg}, \mathrm{Ca}, \mathrm{Ba}$ and $\mathrm{Sr}$ and weak negative correlation with $\mathrm{B}_{2} \mathrm{O}_{3}$ and Na. The weak positive correlation of $\mathrm{C}$ with $\mathrm{Ca}$ and $\mathrm{Mg}$ indicates that some part of carbon in TOT/C is associated with carbonates. The weak positive correlation of $\mathrm{Si}$ with $\mathrm{TOT} / \mathrm{C}$ and $\mathrm{Ca}$ and strong positive correlation with $\mathrm{Al}$ might yield that $\mathrm{Si}$ has multiple origin, both clays and carbonates.

Correlations of Se, Li, As, Cs and Sr which display significant enrichment with respect to ECA and AA indicate that they are derived from a similar source. Very strong correlation of Se with Ca, strong correlation of $\mathrm{Li}$ with $\mathrm{Si}$, strong-very strong correlation of As and Cs with clay group elements (e.g., Si, $\mathrm{Al}, \mathrm{Fe}$ and $\mathrm{K}$ ) and very strong correlation with $\mathrm{Ba}$ are noticeable (table 3 ). Considering negative correlations of these elements and groups determined in the cluster analysis (figure 5), it can be stated that As and Cs are associated with clay group, Se and $\mathrm{Sr}$ are associated with carbonates and $\mathrm{Li}$ is associated with $\mathrm{Si}$.

The cluster analysis (Pearson) performed using the correlation coefficients yielded three different element groups (figure 5). The first group is comprised of $\mathrm{Al}, \mathrm{Fe}, \mathrm{K}, \mathrm{Cs}, \mathrm{Nb}, \mathrm{Rb}, \mathrm{Zr}, \mathrm{Ni}, \mathrm{Pb}$ and $\mathrm{As}$ which are accompanied by REE, Y, Th and $\mathrm{Cu}$. $\mathrm{Ca}$, Se, Ba and Sr form the second group and Si, $\mathrm{U}, \mathrm{Mo}$ and Li form the third group.

\subsection{Rare earth elements}

Although all REEs are determined in all KY and KS2 samples, La, Ce and Pr were detected only in KS1 samples. Averages of REE concentrations (in ppm) in all Kırka samples are La (0.95), Ce (1.85), Pr (0.22), Nd (1.30), Sm (0.28), Eu (0.08), Gd (0.25), Tb (0.05), Dy (0.27), Ho (0.08), Er (0.18), $\mathrm{Tm}$ (0.03), Yb (0.23) and $\mathrm{Lu}(0.03)$.

Considering that studied borate deposit was formed in a sedimentary (lacustrine) environment, REE concentrations were normalized with respect to PAAS (Post-Archean Australian Shales). Normalization was made taking into account that REE patterns of PAAS, average shale and upper crust are almost parallel (Taylor and McLennan 1985).

KS2 with complete REE data reflects a significant negative Eu anomaly as also shown in curves and average values representing $\mathrm{KY}$ area 
Table 2. Trace element contents of Kirka samples (ppm). (1) Krauskopf (1989), (2) Schroll (1975), (3) Abollino et al. (2004), (4) Şahinci (1991).

\begin{tabular}{|c|c|c|c|c|c|c|c|c|c|c|c|c|c|c|c|c|}
\hline Sample & $\mathrm{Se}$ & $\mathrm{Li}$ & As & Cs & $\mathrm{Sr}$ & $\mathrm{Ba}$ & Co & $\mathrm{Nb}$ & $\mathrm{Rb}$ & $\mathrm{Th}$ & $\mathrm{U}$ & $\mathrm{Zr}$ & $\mathrm{Y}$ & Mo & $\mathrm{Cu}$ & $\mathrm{Pb}$ \\
\hline KY26 & 7 & 45.2 & 6 & 6.4 & 50400 & 626 & 0.3 & $<0.1$ & 1.3 & $<0.2$ & $<0.1$ & 0.8 & 0.4 & $<0.1$ & 0.5 & 0.2 \\
\hline KY25 & 5.7 & 126.8 & 7.1 & 46.5 & 8562 & 7 & 0.9 & 0.8 & 23.8 & 2.1 & 0.2 & 2.3 & 8.3 & $<0.1$ & 0.5 & 1.6 \\
\hline KY24 & 1 & 95.6 & $<0.5$ & 17.2 & 1355 & 3 & 3.9 & 0.1 & 7.2 & $<0.2$ & $<0.1$ & 1.8 & 0.2 & $<0.1$ & 0.2 & 0.4 \\
\hline KY23 & 6.1 & 426.1 & 4 & 76.6 & 9047 & 6 & 4.9 & 0.6 & 34.6 & 1 & 0.2 & 1.7 & 1.2 & 0.7 & 0.9 & 1.8 \\
\hline KY22 & 7 & 155.9 & $<0.5$ & 12 & 839.2 & $<1$ & 0.5 & $<0.1$ & 2 & 0.5 & 0.3 & 0.8 & 0.3 & 0.1 & 0.3 & $<0.1$ \\
\hline KY21 & 1.6 & 133.7 & 3 & 32.5 & 1437 & 10 & 0.9 & 0.3 & 8.9 & 0.2 & 0.2 & 1.8 & 0.2 & 0.1 & 0.3 & 0.4 \\
\hline KY20 & 10.3 & 617.8 & 4.2 & 58.1 & 11967 & 44 & $<0.2$ & 0.3 & 14.4 & 0.6 & 0.3 & 0.6 & 0.6 & 1 & 0.8 & 0.7 \\
\hline KY19 & 3.7 & 263.2 & 7.8 & 79.7 & 4254 & 19 & 2 & 0.9 & 34.2 & 1.3 & 0.2 & 2.6 & 1.5 & 0.6 & 0.9 & 2.2 \\
\hline KY18 & 9.5 & 411.4 & 5.8 & 66.4 & 12979 & 45 & 0.5 & 0.8 & 37.8 & 0.9 & 0.3 & 1.9 & 1.4 & 0.7 & $<0.1$ & 1.7 \\
\hline KY17 & 1.1 & 176.9 & 1.5 & 40.6 & 1997 & 3 & $<0.2$ & 0.4 & 13.8 & 0.3 & $<0.1$ & 1.2 & 0.5 & 0.2 & 0.8 & 0.6 \\
\hline KY16 & 10.1 & 329 & 23.9 & 163.6 & 9610 & 16 & 0.7 & 1.9 & 137.7 & 2.3 & 0.2 & 9.3 & 11.2 & 0.4 & 1.9 & 3.1 \\
\hline KY15 & $<0.5$ & 154.1 & $<0.5$ & 1.8 & 22.6 & $<1$ & $<0.2$ & $<0.1$ & 0.8 & $<0.2$ & $<0.1$ & 2.2 & 0.1 & $<0.1$ & 1.3 & $<0.1$ \\
\hline KY14 & 1.8 & 274.1 & $<0.5$ & 30.6 & 953 & 6 & $<0.2$ & $<0.1$ & 6.2 & $<0.2$ & $<0.1$ & 0.9 & 0.2 & $<0.1$ & 1.1 & $<0.1$ \\
\hline KY13 & $<0.5$ & 205.1 & $<0.5$ & 7.7 & 727.9 & 5 & $<0.2$ & $<0.1$ & 2.3 & $<0.2$ & $<0.1$ & $<0.1$ & 0.2 & $<0.1$ & 1.3 & 0.2 \\
\hline KY12 & 0.8 & 257.8 & 10 & 52.3 & 1211 & 8 & 0.3 & 0.7 & 28.5 & 1.1 & 0.2 & 2.8 & 1 & $<0.1$ & 1.4 & 1.3 \\
\hline KY11 & 5.3 & 583.8 & 5.7 & 62 & 2414 & 17 & 0.3 & 0.6 & 35.6 & 0.4 & 0.2 & 4.2 & 0.5 & 0.2 & 1.6 & 1.2 \\
\hline KY10 & 0.6 & 209.9 & 3.3 & 33.4 & 455 & 8 & 0.2 & 0.4 & 19.3 & 0.3 & $<0.1$ & 0.9 & 0.5 & $<0.1$ & 1.4 & 0.6 \\
\hline KY9 & 1 & 415.4 & 22.7 & 962.4 & 450.9 & 23 & 1 & 2 & 133.7 & 0.8 & 0.1 & 7 & 1.4 & 0.1 & 2.9 & 3.7 \\
\hline KY8 & 0.5 & 309.2 & 16.6 & 52.5 & 39 & 52 & 0.4 & 0.9 & 129.8 & $<0.2$ & $<0.1$ & 12.9 & 0.4 & 0.1 & 1.7 & 1.4 \\
\hline KY7 & 3 & 428.3 & 2.3 & 37.2 & 2067 & 6 & $<0.2$ & 0.2 & 7.4 & 0.3 & 0.2 & 0.7 & 0.3 & $<0.1$ & 1.1 & 0.2 \\
\hline KY6 & 0.6 & 210.5 & 3 & 34.7 & 453.8 & 4 & $<0.2$ & 0.1 & 5.8 & $<0.2$ & $<0.1$ & 1.7 & 0.3 & $<0.1$ & 1.3 & 0.3 \\
\hline KY5 & 0.8 & 222.8 & 5.5 & 57.9 & 299.5 & 10 & 0.3 & 0.6 & 37.1 & 0.7 & $<0.1$ & 2.6 & 1 & 0.1 & 1.2 & 1.2 \\
\hline KY4 & 1.1 & 227.4 & 2.2 & 16 & 1196 & 7 & $<0.2$ & 0.1 & 6.6 & 0.3 & $<0.1$ & 0.6 & 0.3 & $<0.1$ & 1.3 & 0.1 \\
\hline KY3 & 6.5 & 693.4 & 3.9 & 62.3 & 2983 & 12 & $<0.2$ & 0.3 & 15.9 & 0.2 & 0.2 & 3.4 & 0.4 & 0.2 & 1.1 & 0.4 \\
\hline KY2 & 5.3 & 667.5 & 3.2 & 74.9 & 2528 & 17 & 0.2 & 0.2 & 16.4 & $<0.2$ & $<0.1$ & 0.4 & 0.4 & 0.2 & 1.1 & 0.4 \\
\hline KY1 & 6.6 & 791.8 & 5.5 & 101.4 & 3024 & 14 & $<0.2$ & 0.3 & 20.3 & $<0.2$ & 0.3 & 0.9 & 0.4 & 0.7 & 1.1 & 0.4 \\
\hline $\begin{array}{c}\text { Average } \\
\text { of } \mathrm{KY}\end{array}$ & 4.04 & 324.33 & 7.01 & 84.10 & 5048.92 & 40.33 & 1.08 & 0.60 & 30.05 & 0.78 & 0.22 & 2.64 & 1.28 & 0.36 & 1.12 & 1.05 \\
\hline KS1-1 & 17.1 & 74.8 & $<0.5$ & 12.6 & 7603 & 3 & 2 & $<0.1$ & 1.4 & $<0.2$ & $<0.1$ & 3.2 & 0.2 & 0.1 & 0.4 & 0.1 \\
\hline KS1-2 & 9.8 & 133.5 & 0.7 & 20.1 & 1393 & 3 & 0.7 & $<0.1$ & 5.3 & $<0.2$ & $<0.1$ & 1.7 & $<0.1$ & $<0.1$ & 0.7 & 0.2 \\
\hline KS1-3 & 6.2 & 346 & 1.6 & 66.2 & 813.3 & 10 & 10.8 & 0.2 & 10.6 & $<0.2$ & $<0.1$ & 5.8 & 0.2 & 0.1 & 0.9 & 0.5 \\
\hline KS1-4 & 16.4 & 615.7 & 8.4 & 153.4 & 5207 & 24 & 3.3 & 0.4 & 28.4 & 0.4 & $<0.1$ & 2.7 & 0.4 & 0.3 & 1 & 0.4 \\
\hline KS1-5 & 7.8 & 162.5 & 3 & 25.8 & 1632 & 6 & 2.7 & 0.1 & 9.4 & 0.2 & $<0.1$ & 4.3 & $<0.1$ & $<0.1$ & 1 & 0.4 \\
\hline KS1-6 & 23.7 & 218.5 & $<0.5$ & 38.7 & 2518 & 9 & 1 & 0.1 & 7.3 & $<0.2$ & $<0.1$ & 2.1 & 0.1 & $<0.1$ & $<0.1$ & $<0.1$ \\
\hline KS1-7 & 18.5 & 256.7 & 0.6 & 41.7 & 4201 & 40 & 0.8 & 0.2 & 7.7 & 0.2 & $<0.1$ & 3.6 & 0.3 & 0.1 & 0.4 & 0.2 \\
\hline KS1-8 & 26.2 & 234.5 & 16.4 & 126.2 & 6349 & 125 & 0.7 & 0.9 & 57.6 & 1.7 & $<0.1$ & 10.9 & 1.1 & 0.7 & 0.8 & 1.9 \\
\hline $\begin{array}{c}\text { Average } \\
\text { of } \mathrm{KS} 1\end{array}$ & 15.71 & 255.28 & 5.12 & 60.59 & 3714.54 & 27.50 & 2.75 & 0.32 & 15.96 & 0.63 & - & 4.29 & 0.38 & 0.26 & 0.74 & 0.53 \\
\hline
\end{tabular}


Table 2. (Continued.)

\begin{tabular}{|c|c|c|c|c|c|c|c|c|c|c|c|c|c|c|c|c|}
\hline Sample & $\mathrm{Se}$ & $\mathrm{Li}$ & As & Cs & $\mathrm{Sr}$ & $\mathrm{Ba}$ & $\mathrm{Co}$ & $\mathrm{Nb}$ & $\mathrm{Rb}$ & $\mathrm{Th}$ & $\mathrm{U}$ & $\mathrm{Zr}$ & $\mathrm{Y}$ & Mo & $\mathrm{Cu}$ & $\mathrm{Pb}$ \\
\hline KS2-1 & 47.4 & 176.7 & 5.3 & 3.4 & 20261 & 125 & 2.1 & 0.1 & 1.9 & 0.2 & 0.2 & 4.4 & 0.6 & 0.2 & 0.4 & 0.4 \\
\hline $\mathrm{KS} 2-2$ & 27.9 & 166.2 & 1.6 & 5.4 & 10273 & 7 & 0.3 & 0.1 & 2 & $<0.2$ & 0.2 & 2.7 & 0.6 & $<0.1$ & 0.4 & 0.2 \\
\hline KS2-3 & 7.4 & 105.6 & 1 & 20.1 & 12172 & 10 & 0.9 & $<0.1$ & 5.9 & $<0.2$ & 0.1 & 1.4 & 0.8 & 0.2 & 0.9 & 0.4 \\
\hline KS2-4 & 4.8 & 258.1 & 1 & 17.6 & 4996 & 14 & 0.4 & 0.2 & 6.6 & $<0.2$ & $<0.1$ & 1.5 & 0.4 & 0.3 & 1.6 & 0.3 \\
\hline $\mathrm{KS} 2-5$ & 3.1 & 245.8 & 3.5 & 21.9 & 4145 & 10 & $<0.2$ & 0.3 & 12.1 & 0.3 & 0.2 & 2.1 & 0.8 & 0.2 & 1.5 & 0.5 \\
\hline KS2-6 & 13.4 & 169.8 & 1.4 & 4.6 & 9305 & 19 & $<0.2$ & 0.2 & 5 & 0.3 & 0.1 & 1.4 & 0.6 & $<0.1$ & 0.6 & 0.4 \\
\hline $\mathrm{KS} 2-7$ & 9.9 & 91.6 & 5 & 26.3 & 13389 & 22 & 0.8 & 0.5 & 24.5 & 1 & 0.2 & 3.6 & 3.3 & 0.2 & 1.2 & 1.3 \\
\hline KS2-8 & 9.9 & 103.7 & 4.5 & 20.1 & 10271 & 44 & 0.5 & 0.3 & 16.2 & 0.3 & 0.1 & 3.9 & 3.3 & 0.2 & 0.9 & 1.4 \\
\hline KS2-9 & 13 & 221.5 & 5.2 & 31.8 & 7563 & 26 & $<0.2$ & 0.5 & 24.9 & 1 & 0.2 & 3.2 & 1.5 & 0.2 & 0.7 & 2 \\
\hline KS2-10 & 28.5 & 227.1 & 2.4 & 33.7 & 5412 & 22 & 1 & 0.4 & 18.5 & 0.4 & 0.2 & 2.4 & 0.6 & 0.1 & 1.2 & 0.5 \\
\hline KS2-11 & 13.1 & 300.7 & 0.9 & 23.3 & 5317 & 41 & $<0.2$ & $<0.1$ & 2.7 & $<0.2$ & 0.2 & 1 & 0.4 & $<0.1$ & 0.3 & 0.1 \\
\hline KS2-12 & 8.6 & 80.3 & 0.5 & 10.6 & 1949 & 5 & 0.2 & 0.1 & 7.1 & $<0.2$ & $<0.1$ & 1.1 & 1.8 & $<0.1$ & 0.4 & 0.3 \\
\hline KS2-13 & 13.2 & 675.4 & 3.5 & 76.5 & 4713 & 32 & $<0.2$ & 0.5 & 30.9 & 0.8 & 0.4 & 4.1 & 0.9 & 0.7 & 0.8 & 1.1 \\
\hline $\begin{array}{c}\text { Average } \\
\text { of KS2 }\end{array}$ & 15.40 & 217.12 & 2.75 & 22.72 & 8443.54 & 29.00 & 0.78 & 0.29 & 12.18 & 0.54 & 0.19 & 2.52 & 1.20 & 0.26 & 0.84 & 0.68 \\
\hline $\begin{array}{l}\text { Average of } \\
\text { all samples }\end{array}$ & 9.40 & 282.92 & 5.34 & 63.12 & 5760.73 & 34.78 & 1.42 & 0.46 & 22.71 & 0.69 & 0.21 & 2.89 & 1.14 & 0.31 & 0.98 & 0.85 \\
\hline $\begin{array}{l}\text { Standard } \\
\text { deviation }\end{array}$ & 9.42 & 186.93 & 5.51 & 138.92 & 8047.13 & 93.85 & 2.06 & 0.43 & 31.91 & 0.57 & 0.07 & 2.62 & 2.03 & 0.26 & 0.52 & 0.83 \\
\hline Various rates & $\begin{array}{l}<0.5- \\
47.4\end{array}$ & $\begin{array}{c}45.2- \\
791.8\end{array}$ & $\begin{array}{c}<0.5- \\
23.9\end{array}$ & $\begin{array}{r}1.8^{-} \\
926.4\end{array}$ & $\begin{array}{l}22.6- \\
50400\end{array}$ & $\begin{array}{l}<1- \\
626\end{array}$ & $\begin{array}{l}<0.2- \\
10.8\end{array}$ & $\begin{array}{c}<0.1- \\
1.9\end{array}$ & $\begin{array}{r}0.8^{-} \\
137.7\end{array}$ & $\begin{array}{c}<0.2- \\
2.1\end{array}$ & $\begin{array}{c}<0.1- \\
0.4\end{array}$ & $\begin{array}{c}<0.1- \\
4.4\end{array}$ & $\begin{array}{l}<0.1- \\
11.2\end{array}$ & $\begin{array}{c}<0.1- \\
0.7\end{array}$ & $\begin{array}{c}<0.1- \\
2.9\end{array}$ & $\begin{array}{c}<0.1- \\
3.1\end{array}$ \\
\hline $\begin{array}{l}\text { Average } \\
\text { (earth } \\
\text { crust) (1) }\end{array}$ & 0.05 & 20 & 1.8 & 3 & 375 & 500 & 22 & 20 & 90 & 8.5 & 2.7 & 165 & 35 & 1.5 & 50 & 12.5 \\
\hline $\begin{array}{l}\text { Average } \\
\text { (Andesite) (2) }\end{array}$ & 0.05 & 20 & 1.9 & 2.3 & 800 & 714 & 10 & 20 & 72 & 7 & 1.8 & 260 & 25 & 0.9 & 35 & 15 \\
\hline $\begin{array}{l}\text { Average } \\
\text { (fresh- } \\
\text { waters) (3) }\end{array}$ & $0.1 \cdot 10^{-3}$ & $1 \cdot 10^{-3}$ & $2 \cdot 10^{-3}$ & $\begin{array}{l}1.8 \cdot 10^{-3} \\
(4)\end{array}$ & $50 \cdot 10^{-3}$ & $10 \cdot 10^{-3}$ & $\begin{array}{c}0.05 \\
\cdot 10^{-3}\end{array}$ & - & - & - & $\begin{array}{l}0.05 \\
\cdot 10^{-3}\end{array}$ & - & - & $1 \cdot 10^{-3}$ & $\begin{array}{l}1.8 \\
\cdot 10^{-3}\end{array}$ & $\begin{array}{c}0.2 \\
\cdot 10^{-3}\end{array}$ \\
\hline
\end{tabular}


Table 2. (Continued.)

\begin{tabular}{|c|c|c|c|c|c|c|c|c|c|c|c|c|c|c|c|}
\hline Sample & $\mathrm{Ni}$ & $\mathrm{La}$ & $\mathrm{Ce}$ & $\operatorname{Pr}$ & $\mathrm{Nd}$ & $\mathrm{Sm}$ & $\mathrm{Eu}$ & $\mathrm{Gd}$ & $\mathrm{Tb}$ & Dy & Но & Er & $\mathrm{Tm}$ & $\mathrm{Yb}$ & $\mathrm{Lu}$ \\
\hline KY26 & $<0.1$ & 0.1 & 0.2 & 0.04 & $<0.3$ & $<0.05$ & $<0.02$ & $<0.05$ & $<0.01$ & $<0.05$ & $<0.02$ & $<0.03$ & $<0.01$ & $<0.05$ & $<0.01$ \\
\hline KY25 & 1.3 & 3.8 & 8.2 & 0.97 & 3.6 & 0.91 & 0.09 & 0.93 & 0.19 & 1.14 & 0.24 & 0.74 & 0.12 & 0.88 & 0.12 \\
\hline KY24 & 0.2 & 0.2 & 0.4 & 0.05 & $<0.3$ & $<0.05$ & $<0.02$ & $<0.05$ & 0.01 & $<0.05$ & $<0.02$ & $<0.03$ & $<0.01$ & $<0.05$ & $<0.01$ \\
\hline KY23 & 0.9 & 1 & 2.2 & 0.24 & 1 & 0.18 & $<0.02$ & 0.19 & 0.03 & 0.17 & 0.04 & 0.1 & 0.02 & 0.11 & 0.02 \\
\hline KY22 & 0.6 & 0.2 & 0.4 & 0.05 & $<0.3$ & $<0.05$ & $<0.02$ & $<0.05$ & $<0.01$ & $<0.05$ & $<0.02$ & $<0.03$ & $<0.01$ & $<0.05$ & $<0.01$ \\
\hline KY21 & 0.2 & 0.6 & 1 & 0.13 & 0.6 & 0.12 & $<0.02$ & 0.09 & $<0.01$ & $<0.05$ & $<0.02$ & $<0.03$ & $<0.01$ & $<0.05$ & $<0.01$ \\
\hline KY20 & 0.8 & 0.5 & 1.1 & 0.11 & 0.4 & 0.07 & $<0.02$ & 0.07 & 0.02 & 0.07 & 0.02 & 0.05 & $<0.01$ & 0.06 & 0.01 \\
\hline KY19 & 1.1 & 1.2 & 2.4 & 0.3 & 1.3 & 0.27 & 0.03 & 0.24 & 0.04 & 0.22 & 0.05 & 0.14 & 0.02 & 0.15 & 0.02 \\
\hline KY18 & 0.2 & 1.7 & 3.2 & 0.37 & 1.4 & 0.27 & 0.03 & 0.24 & 0.04 & 0.19 & 0.04 & 0.13 & 0.02 & 0.11 & 0.02 \\
\hline KY17 & 0.4 & 0.4 & 0.8 & 0.09 & 0.4 & 0.08 & $<0.02$ & 0.08 & 0.01 & 0.08 & $<0.02$ & 0.04 & $<0.01$ & $<0.05$ & $<0.01$ \\
\hline KY16 & 4.9 & 10.4 & 23.8 & 2.48 & 9.6 & 2.06 & 0.29 & 2.05 & 0.33 & 1.86 & 0.38 & 1.08 & 0.15 & 0.92 & 0.14 \\
\hline KY15 & 0.1 & $<0.1$ & 0.2 & $<0.02$ & $<0.3$ & $<0.05$ & $<0.02$ & $<0.05$ & $<0.01$ & $<0.05$ & $<0.02$ & $<0.03$ & $<0.01$ & $<0.05$ & $<0.01$ \\
\hline KY14 & 0.3 & 0.1 & 0.2 & $<0.02$ & $<0.3$ & $<0.05$ & $<0.02$ & $<0.05$ & $<0.01$ & $<0.05$ & $<0.02$ & $<0.03$ & $<0.01$ & $<0.05$ & $<0.01$ \\
\hline KY13 & 0.2 & 0.1 & 0.2 & $<0.02$ & $<0.3$ & $<0.05$ & $<0.02$ & $<0.05$ & $<0.01$ & $<0.05$ & $<0.02$ & $<0.03$ & $<0.01$ & $<0.05$ & $<0.01$ \\
\hline KY12 & 1.6 & 0.8 & 1.6 & 0.17 & 0.8 & 0.16 & $<0.02$ & 0.15 & 0.02 & 0.12 & 0.02 & 0.09 & 0.02 & 0.11 & 0.02 \\
\hline KY11 & 0.8 & 0.5 & 0.9 & 0.09 & 0.4 & 0.08 & $<0.02$ & 0.07 & 0.01 & 0.05 & $<0.02$ & 0.04 & $<0.01$ & $<0.05$ & $<0.01$ \\
\hline KY10 & 0.7 & 0.4 & 0.9 & 0.08 & 0.5 & 0.07 & $<0.02$ & 0.08 & 0.01 & 0.07 & $<0.02$ & 0.04 & $<0.01$ & $<0.05$ & $<0.01$ \\
\hline KY9 & 5.4 & 1.9 & 3.5 & 0.38 & 1.5 & 0.26 & 0.03 & 0.23 & 0.04 & 0.25 & 0.06 & 0.18 & 0.02 & 0.13 & 0.02 \\
\hline KY8 & 1.8 & 0.6 & 1 & 0.1 & 0.6 & 0.07 & $<0.02$ & 0.07 & 0.01 & 0.06 & $<0.02$ & $<0.03$ & $<0.01$ & $<0.05$ & $<0.01$ \\
\hline KY7 & $<0.1$ & 0.2 & 0.3 & 0.02 & $<0.3$ & $<0.05$ & $<0.02$ & $<0.05$ & $<0.01$ & $<0.05$ & $<0.02$ & $<0.03$ & $<0.01$ & $<0.05$ & $<0.01$ \\
\hline KY6 & 0.4 & 0.3 & 0.5 & 0.04 & $<0.3$ & $<0.05$ & $<0.02$ & $<0.05$ & $<0.01$ & $<0.05$ & $<0.02$ & $<0.03$ & $<0.01$ & $<0.05$ & $<0.01$ \\
\hline KY5 & 1.5 & 0.8 & 1.8 & 0.17 & 0.7 & 0.14 & $<0.02$ & 0.16 & 0.02 & 0.11 & 0.03 & 0.06 & 0.02 & 0.07 & 0.01 \\
\hline KY4 & 0.3 & 0.4 & 0.5 & 0.04 & $<0.3$ & $<0.05$ & $<0.02$ & $<0.05$ & $<0.01$ & $<0.05$ & $<0.02$ & $<0.03$ & $<0.01$ & $<0.05$ & $<0.01$ \\
\hline KY3 & 0.5 & 0.4 & 0.6 & 0.05 & 0.3 & $<0.05$ & $<0.02$ & 0.06 & $<0.01$ & $<0.05$ & $<0.02$ & $<0.03$ & $<0.01$ & $<0.05$ & $<0.01$ \\
\hline KY2 & 0.2 & 0.2 & 0.4 & 0.03 & $<0.3$ & $<0.05$ & $<0.02$ & 0.06 & $<0.01$ & 0.05 & $<0.02$ & $<0.03$ & $<0.01$ & $<0.05$ & $<0.01$ \\
\hline KY1 & 0.7 & 0.3 & 0.4 & 0.04 & $<0.3$ & $<0.05$ & $<0.02$ & 0.05 & $<0.01$ & $<0.05$ & $<0.02$ & $<0.03$ & $<0.01$ & $<0.05$ & $<0.01$ \\
\hline $\begin{array}{c}\text { Average } \\
\text { of KY }\end{array}$ & 1.05 & 1.08 & 2.18 & 0.26 & 1.54 & 0.34 & 0.09 & 0.28 & 0.06 & 0.32 & 0.10 & 0.22 & 0.05 & 0.28 & 0.04 \\
\hline KS1-1 & $<0.1$ & 0.2 & 0.3 & 0.02 & $<0.3$ & $<0.05$ & $<0.02$ & $<0.05$ & $<0.01$ & $<0.05$ & $<0.02$ & $<0.03$ & $<0.01$ & $<0.05$ & $<0.01$ \\
\hline KS1-2 & $<0.1$ & 0.1 & 0.1 & $<0.02$ & $<0.3$ & $<0.05$ & $<0.02$ & $<0.05$ & $<0.01$ & $<0.05$ & $<0.02$ & $<0.03$ & $<0.01$ & $<0.05$ & $<0.01$ \\
\hline KS1-3 & 0.2 & 0.3 & 0.4 & 0.02 & $<0.3$ & $<0.05$ & $<0.02$ & $<0.05$ & $<0.01$ & $<0.05$ & $<0.02$ & $<0.03$ & $<0.01$ & $<0.05$ & $<0.01$ \\
\hline KS1-4 & 0.4 & 0.5 & 0.8 & 0.08 & $<0.3$ & $<0.05$ & $<0.02$ & $<0.05$ & $<0.01$ & $<0.05$ & $<0.02$ & $<0.03$ & $<0.01$ & $<0.05$ & $<0.01$ \\
\hline KS1-5 & $<0.1$ & 0.3 & 0.4 & $<0.02$ & $<0.3$ & $<0.05$ & $<0.02$ & $<0.05$ & $<0.01$ & $<0.05$ & $<0.02$ & $<0.03$ & $<0.01$ & $<0.05$ & $<0.01$ \\
\hline KS1-6 & $<0.1$ & 0.2 & 0.3 & $<0.02$ & $<0.3$ & $<0.05$ & $<0.02$ & $<0.05$ & $<0.01$ & $<0.05$ & $<0.02$ & $<0.03$ & $<0.01$ & $<0.05$ & $<0.01$ \\
\hline KS1-7 & 0.4 & 0.4 & 0.6 & 0.06 & $<0.3$ & $<0.05$ & $<0.02$ & $<0.05$ & $<0.01$ & $<0.05$ & $<0.02$ & $<0.03$ & $<0.01$ & $<0.05$ & $<0.01$ \\
\hline KS1-8 & 0.8 & 2.1 & 3.8 & 0.34 & $<0.3$ & $<0.05$ & $<0.02$ & $<0.05$ & $<0.01$ & $<0.05$ & $<0.02$ & $<0.03$ & $<0.01$ & $<0.05$ & $<0.01$ \\
\hline $\begin{array}{c}\text { Average } \\
\text { of KS1 }\end{array}$ & 0.45 & 0.51 & 0.84 & 0.10 & - & - & - & - & - & - & - & - & - & - & - \\
\hline
\end{tabular}


Table 2. (Continued.)

\begin{tabular}{|c|c|c|c|c|c|c|c|c|c|c|c|c|c|c|c|}
\hline Sample & $\mathrm{Ni}$ & $\mathrm{La}$ & $\mathrm{Ce}$ & $\operatorname{Pr}$ & $\mathrm{Nd}$ & $\mathrm{Sm}$ & $\mathrm{Eu}$ & $\mathrm{Gd}$ & $\mathrm{Tb}$ & Dy & Ho & Er & $\mathrm{Tm}$ & $\mathrm{Yb}$ & $\mathrm{Lu}$ \\
\hline KS2-1 & $<0.1$ & 0.5 & 0.6 & 0.08 & 0.5 & 0.05 & $<0.02$ & 0.08 & 0.02 & 0.05 & 0.03 & 0.03 & 0.02 & $<0.05$ & 0.02 \\
\hline $\mathrm{KS} 2-2$ & $<0.1$ & 0.4 & 0.5 & 0.05 & 0.3 & $<0.05$ & $<0.02$ & 0.07 & 0.01 & $<0.05$ & $<0.02$ & $<0.03$ & 0.01 & $<0.05$ & $<0.01$ \\
\hline KS2-3 & 0.3 & 0.5 & 0.7 & 0.07 & 0.5 & 0.07 & $<0.02$ & 0.1 & 0.01 & 0.06 & $<0.02$ & 0.05 & 0.01 & $<0.05$ & 0.01 \\
\hline KS2-4 & 0.3 & 0.3 & 0.4 & 0.04 & 0.3 & $<0.05$ & $<0.02$ & 0.07 & $<0.01$ & $<0.05$ & $<0.02$ & $<0.03$ & $<0.01$ & $<0.05$ & $<0.01$ \\
\hline $\mathrm{KS} 2-5$ & 1.1 & 0.6 & 1.1 & 0.11 & 0.6 & 0.09 & $<0.02$ & 0.12 & 0.02 & 0.07 & 0.02 & 0.06 & 0.01 & $<0.05$ & $<0.01$ \\
\hline KS2-6 & 0.5 & 0.5 & 0.9 & 0.07 & 0.4 & 0.05 & $<0.02$ & 0.09 & 0.01 & $<0.05$ & $<0.02$ & 0.04 & $<0.01$ & $<0.05$ & $<0.01$ \\
\hline $\mathrm{KS} 2-7$ & 1 & 2.4 & 4.9 & 0.53 & 2.2 & 0.41 & 0.06 & 0.46 & 0.09 & 0.46 & 0.09 & 0.27 & 0.04 & 0.23 & 0.03 \\
\hline KS2-8 & 0.3 & 3.2 & 7 & 0.83 & 3.5 & 0.57 & 0.11 & 0.53 & 0.09 & 0.48 & 0.09 & 0.31 & 0.04 & 0.22 & 0.03 \\
\hline KS2-9 & 0.9 & 1.9 & 3.6 & 0.37 & 1.4 & 0.29 & 0.06 & 0.25 & 0.05 & 0.17 & 0.05 & .14 & 0.03 & 0.1 & 0.03 \\
\hline KS2-10 & $<0.1$ & 0.5 & 0.9 & 0.08 & 0.5 & 0.06 & $<0.02$ & 0.08 & 0.01 & 0.05 & $<0.02$ & $<0.03$ & $<0.01$ & $<0.05$ & $<0.01$ \\
\hline KS2-11 & 0.9 & 0.3 & 0.3 & 0.03 & $<0.3$ & $<0.05$ & $<0.02$ & $<0.05$ & $<0.01$ & $<0.05$ & $<0.02$ & $<0.03$ & $<0.01$ & $<0.05$ & $<0.01$ \\
\hline KS2-12 & 0.1 & 0.5 & 0.9 & 0.13 & 1 & 0.18 & 0.03 & 0.3 & 0.04 & 0.25 & 0.05 & 0.16 & 0.02 & 0.08 & 0.02 \\
\hline KS2-13 & 0.8 & 1 & 1.7 & 0.18 & 0.9 & 0.16 & 0.02 & 0.15 & 0.02 & 0.12 & 0.03 & 0.06 & 0.01 & 0.05 & 0.01 \\
\hline $\begin{array}{c}\text { Average } \\
\text { of KS2 }\end{array}$ & 0.62 & 0.97 & 1.81 & 0.20 & 1.01 & 0.19 & 0.06 & 0.19 & 0.03 & 0.19 & 0.05 & 0.12 & 0.02 & 0.14 & 0.02 \\
\hline $\begin{array}{l}\text { Average of } \\
\text { all samples }\end{array}$ & 0.87 & 0.95 & 1.85 & 0.22 & 1.30 & 0.28 & 0.08 & 0.25 & 0.05 & 0.27 & 0.08 & 0.18 & 0.03 & 0.23 & 0.03 \\
\hline $\begin{array}{l}\text { Standard } \\
\text { deviation }\end{array}$ & 1.11 & 1.64 & 3.70 & 0.42 & 1.87 & 0.43 & 0.08 & 0.39 & 0.07 & 0.42 & 0.10 & 0.26 & 0.04 & 0.29 & 0.04 \\
\hline Various & $\begin{array}{c}<0.1- \\
5.4\end{array}$ & $\begin{array}{l}<0.1- \\
10\end{array}$ & $\begin{array}{l}0.1- \\
23.8\end{array}$ & $\begin{array}{c}<0.02- \\
2.48\end{array}$ & $\begin{array}{c}<0.3- \\
9.6\end{array}$ & $\begin{array}{c}<0.05^{-} \\
2.06\end{array}$ & $\begin{array}{c}<0.02- \\
0.29\end{array}$ & $\begin{array}{c}<0.05- \\
2.05\end{array}$ & $\begin{array}{c}<0.01- \\
0.33\end{array}$ & $\begin{array}{c}<0.05- \\
1.86\end{array}$ & $\begin{array}{c}<0.02- \\
0.38\end{array}$ & $\begin{array}{c}<0.03- \\
1.08\end{array}$ & $\begin{array}{c}<0.01- \\
0.15\end{array}$ & $\begin{array}{c}<0.05- \\
0.92\end{array}$ & $\begin{array}{c}<0.01- \\
0.14\end{array}$ \\
\hline $\begin{array}{l}\text { Average } \\
\text { (earth } \\
\text { crust) (1) }\end{array}$ & 75 & 35 & 70 & 8 & 30 & 7 & 1.2 & 7 & 1 & 6 & 1.5 & 3.5 & 0.5 & 3.5 & 0.6 \\
\hline $\begin{array}{l}\text { Average } \\
\text { (Andesite) (2) }\end{array}$ & 55 & - & - & - & - & - & - & - & - & - & - & - & - & - & - \\
\hline $\begin{array}{l}\text { Average } \\
\text { (fresh- } \\
\text { waters) (3) }\end{array}$ & $\begin{array}{l}0.3 \\
\cdot 10^{-3}\end{array}$ & - & - & - & - & - & - & - & - & - & - & - & - & - & - \\
\hline
\end{tabular}


Table 3. Correlation coefficicents for Kirka samples.

\begin{tabular}{|c|c|c|c|c|c|c|c|c|c|c|c|c|c|c|c|c|c|c|c|c|c|c|c|c|c|c|c|}
\hline & TOT/C & $\mathrm{B}_{2} \mathrm{O}_{3}$ & $\mathrm{Si}$ & $\mathrm{Al}$ & $\mathrm{Fe}$ & $\mathrm{Mg}$ & $\mathrm{Ca}$ & $\mathrm{Na}$ & $\mathrm{K}$ & $\mathrm{Li}$ & $\mathrm{Ba}$ & Co & Cs & $\mathrm{Nb}$ & $\mathrm{Rb}$ & $\mathrm{Sr}$ & Th & $\mathrm{U}$ & $\mathrm{Zr}$ & Y & Mo & $\mathrm{Cu}$ & $\mathrm{Pb}$ & $\mathrm{Ni}$ & As & $\mathrm{Se}$ & REE \\
\hline ТОТ/C & 1.00 & -0.49 & 0.36 & 0.08 & -0.08 & 0.39 & 0.33 & -0.31 & 0.11 & 0.14 & 0.36 & 0.14 & 0.07 & 0.07 & 0.10 & 0.31 & 0.17 & 0.06 & 0.19 & 0.13 & 0.10 & -0.18 & 0.05 & 0.06 & 0.20 & 0.28 & 0.11 \\
\hline $\mathrm{B}_{2} \mathrm{O}_{3}$ & & 1.00 & -0.71 & -0.17 & -0.03 & -0.64 & -0.17 & 0.27 & -0.20 & -0.65 & 0.07 & 0.08 & -0.12 & -0.22 & -0.19 & 0.11 & -0.27 & -0.39 & -0.16 & -0.01 & -0.54 & 0.12 & -0.22 & -0.11 & -0.23 & -0.07 & -0.03 \\
\hline $\mathrm{Si}$ & & & 1.00 & 0.61 & 0.42 & 0.29 & 0.23 & -0.16 & 0.63 & 0.67 & 0.01 & 0.05 & 0.38 & 0.62 & 0.65 & -0.02 & 0.49 & 0.36 & 0.62 & 0.22 & 0.72 & 0.21 & 0.57 & 0.43 & 0.67 & 0.20 & 0.31 \\
\hline $\mathrm{Al}$ & & & & 1.00 & 0.84 & -0.07 & -0.12 & 0.01 & 0.97 & 0.12 & -0.01 & -0.04 & 0.51 & 0.85 & 0.96 & -0.07 & 0.53 & 0.10 & 0.81 & 0.46 & 0.23 & 0.54 & 0.80 & 0.78 & 0.88 & -0.14 & 0.55 \\
\hline $\mathrm{Fe}$ & & & & & 1.00 & -0.07 & -0.23 & 0.05 & 0.76 & 0.12 & -0.06 & 0.01 & 0.68 & 0.90 & 0.91 & -0.08 & 0.52 & 0.11 & 0.55 & 0.51 & 0.16 & 0.56 & 0.82 & 0.89 & 0.82 & -0.24 & 0.60 \\
\hline $\mathrm{Mg}$ & & & & & & 1.00 & 0.03 & -0.57 & -0.10 & 0.21 & -0.06 & 0.20 & -0.03 & 0.05 & -0.08 & -0.07 & 0.22 & 0.34 & -0.08 & 0.00 & 0.35 & -0.38 & 0.07 & -0.08 & -0.03 & 0.01 & -0.05 \\
\hline $\mathrm{Ca}$ & & & & & & & 1.00 & -0.67 & -0.08 & -0.01 & 0.21 & -0.03 & -0.16 & -0.08 & -0.13 & 0.46 & 0.12 & 0.36 & 0.07 & 0.13 & 0.27 & -0.47 & -0.01 & -0.17 & -0.05 & 0.86 & 0.14 \\
\hline $\mathrm{Na}$ & & & & & & & & 1.00 & 0.03 & 0.21 & -0.22 & -0.01 & 0.16 & -0.04 & 0.08 & -0.42 & -0.30 & -0.42 & 0.00 & -0.24 & -0.29 & 0.61 & -0.12 & 0.09 & 0.01 & -0.54 & -0.20 \\
\hline K & & & & & & & & & 1.00 & 0.14 & 0.00 & -0.04 & 0.36 & 0.75 & 0.92 & -0.08 & 0.45 & 0.05 & 0.84 & 0.42 & 0.22 & 0.46 & 0.68 & 0.67 & 0.82 & -0.09 & 0.51 \\
\hline $\mathrm{Li}$ & & & & & & & & & & 1.00 & -0.16 & 0.00 & 0.26 & 0.23 & 0.24 & -0.19 & 0.05 & 0.41 & 0.05 & -0.09 & 0.57 & 0.27 & 0.15 & 0.17 & 0.21 & -0.06 & -0.04 \\
\hline $\mathrm{Ba}$ & & & & & & & & & & & 1.00 & -0.06 & -0.04 & -0.07 & -0.03 & 0.88 & -0.04 & -0.10 & 0.03 & -0.04 & 0.00 & -0.15 & -0.03 & -0.08 & 0.14 & 0.15 & -0.05 \\
\hline Co & & & & & & & & & & & & 1.00 & 0.05 & -0.01 & -0.02 & -0.04 & -0.02 & -0.17 & 0.19 & -0.05 & 0.04 & -0.11 & 0.04 & -0.07 & -0.04 & 0.07 & -0.04 \\
\hline Cs & & & & & & & & & & & & & 1.00 & 0.70 & 0.65 & -0.12 & 0.24 & 0.03 & 0.34 & 0.13 & 0.10 & 0.58 & 0.64 & 0.75 & 0.64 & -0.12 & 0.19 \\
\hline $\mathrm{Nb}$ & & & & & & & & & & & & & & 1.00 & 0.91 & -0.06 & 0.74 & 0.24 & 0.63 & 0.60 & 0.33 & 0.56 & 0.94 & 0.90 & 0.91 & -0.11 & 0.68 \\
\hline $\mathrm{Rb}$ & & & & & & & & & & & & & & & 1.00 & -0.10 & 0.53 & 0.09 & 0.78 & 0.49 & 0.24 & 0.61 & 0.82 & 0.87 & 0.92 & -0.13 & 0.59 \\
\hline $\mathrm{Sr}$ & & & & & & & & & & & & & & & & 1.00 & 0.08 & 0.12 & -0.06 & 0.15 & 0.14 & -0.27 & 0.02 & -0.10 & 0.08 & 0.33 & 0.13 \\
\hline Th & & & & & & & & & & & & & & & & & 1.00 & 0.39 & 0.39 & 0.77 & 0.41 & 0.16 & 0.77 & 0.58 & 0.64 & 0.04 & 0.75 \\
\hline $\mathrm{U}$ & & & & & & & & & & & & & & & & & & 1.00 & -0.06 & 0.24 & 0.53 & -0.10 & 0.28 & 0.17 & 0.12 & 0.17 & 0.24 \\
\hline $\mathrm{Zr}$ & & & & & & & & & & & & & & & & & & & 1.00 & 0.32 & 0.15 & 0.35 & 0.58 & 0.53 & 0.76 & 0.19 & 0.42 \\
\hline Y & & & & & & & & & & & & & & & & & & & & 1.00 & 0.12 & 0.17 & 0.59 & 0.58 & 0.53 & 0.00 & 0.96 \\
\hline Mo & & & & & & & & & & & & & & & & & & & & & 1.00 & -0.01 & 0.39 & 0.14 & 0.28 & 0.14 & 0.19 \\
\hline $\mathrm{Cu}$ & & & & & & & & & & & & & & & & & & & & & & 1.00 & 0.47 & 0.66 & 0.57 & -0.09 & 0.25 \\
\hline $\mathrm{Pb}$ & & & & & & & & & & & & & & & & & & & & & & & 1.00 & 0.82 & 0.84 & -0.21 & 0.66 \\
\hline $\mathrm{Ni}$ & & & & & & & & & & & & & & & & & & & & & & & & 1.00 & 0.85 & -0.01 & 0.66 \\
\hline As & & & & & & & & & & & & & & & & & & & & & & & & & 1.00 & 1.00 & 0.62 \\
\hline $\mathrm{Se}$ & & & & & & & & & & & & & & & & & & & & & & & & & & & 0.01 \\
\hline REE & & & & & & & & & & & & & & & & & & & & & & & & & & & 1.00 \\
\hline
\end{tabular}




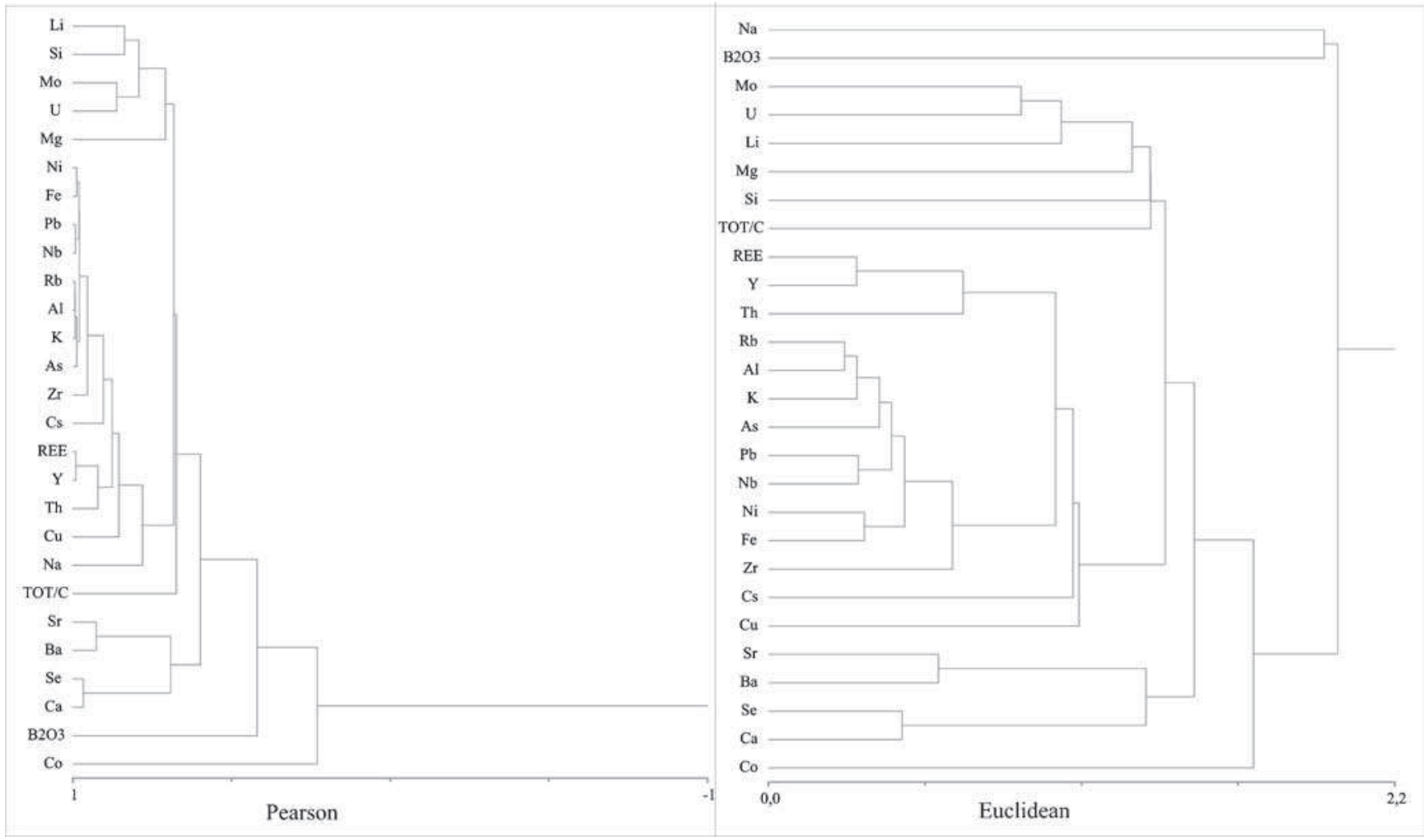

Figure 5. Cluster dendrogram for elements of Kırka samples.

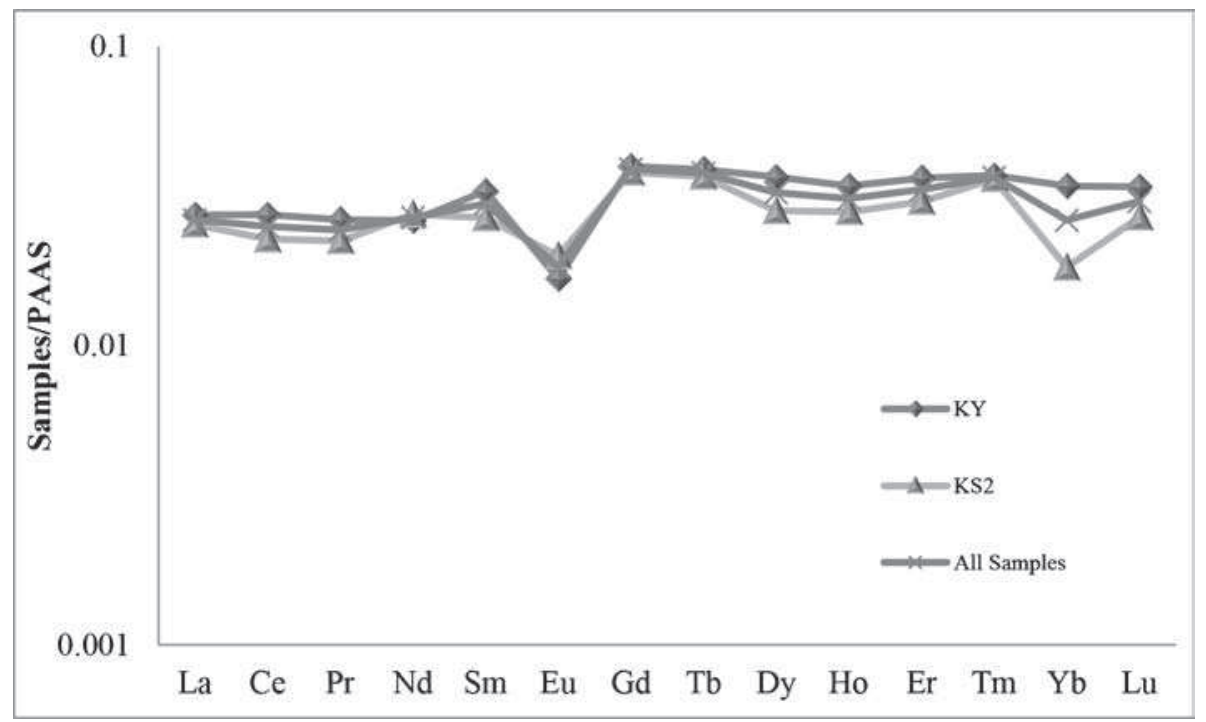

Figure 6. REE distributions for Kırka borate samples (normalized according to Taylor and McLennan 1985).

(figure 6). Except for this anomaly, curves show a flat pattern. Concentrations of heavy rare earth elements (HREE) are higher than those of light rare earth elements (LREE). The negative Eu anomaly is detected in many sedimentary rocks. In order to have more information on environmental conditions, concentrations of rare earth elements in natural waters and hydrothermal solutions are to be known. McLennan (1989) who classified hydrothermal waters as oceanic and terrestrial types, divided terrestrial hydrothermal waters into two categories: low-pH and high-pH waters. Waters showing a negative Eu anomaly was described by McLennan (1989) as high-pH hydrothermal waters of terrestrial environment. Based on this, REE concentrations of Kirka borate deposit indicate that high-pH hydrothermal waters contributed to borate formation process. 
Alternatively, negative Eu anomaly is thought to represent anoxic reducing environment (Constantopoulos 1988; Henderson 1984). Hydrothermal solutions (Sverjensky 1984; Bau 1991) and leaching (Bence and Taylor 1985) give rise to reducing of $\mathrm{Eu}^{3+}$ to $\mathrm{Eu}^{2+}$ and as a result a strong negative Eu anomaly appears.

This negative Eu anomaly needs to be explained considering that borates formed in an oxygenated lacustrine environment. In oxygenated environments, $\mathrm{Eu}^{2+}$ is easily oxidized to $\mathrm{Eu}^{3+}$ which contributes to borate formation. Since its ionic radius is similar to that of $\mathrm{Ca}$ and $\mathrm{Na}$, this should result in a positive Eu anomaly (Weil and Drake 1973; Bau 1991; Ehinola et al. 2010). Therefore, there must be some explanation for the negative $\mathrm{Eu}$ anomaly in Kirka borates. First, it can be suggested that sufficient amount of Eu was not transported to the lake environment by hydrothermal waters and due to reduced nature of the fluid or early precipitation of feldspar (retention in feldspar) before the REEs became a part of the lacustrie geochemical enviroment. In addition, $\mathrm{H}_{2}$ S-bearing hydrothermal solutions make the environment to have a partly reducing character. Considering all these data and suggestions, it is proposed that the Kirka borate deposit was formed in a sedimentary environment with contribution from high-pH hydrothermal waters, and during the leaching of country rocks, $\mathrm{Eu}^{3+}$ was reduced to $\mathrm{Eu}^{2+}$ which caused a negative Eu anomaly.

\section{Conclusions}

- The Kirka borate deposits were formed in Miocene lacustrine basins which are associated with volcanic activity which lasted from Paleogene to the beginning of Quaternary. Borate mineralization generally shows a lenticular structure and is interlayered with claystone, mudstone, marl, tuff and thin-layered limestone (Helvac1 2003).

- The mineral paragenesis is composed of borax, tincalconite, ulexite, kurnakovite, probertite, tunellite, colemanite, dolomite, smectite group minerals, illite and some firstly reported minerals for the Kirka deposit including hydrochloroborite, brianroulstonite, hilgardite-4M and searlesite minerals.

- Based on major element abundances, Ca-borates occur at western part of the deposit, while Naand Mg-borates are dominant at the area of management.

- Most of major and trace elements (e.g., Si, Al, $\mathrm{Fe}, \mathrm{K}, \mathrm{Cs}, \mathrm{Nb}, \mathrm{Rb}, \mathrm{Zr}, \mathrm{Ni}, \mathrm{Pb}, \mathrm{As}$ ) are mobilized as a result of alteration of silicate rocks and transported to the lake environment in association with detrital clays. Li and Mo which have an affinity for Si rather than $\mathrm{Al}$, can be included to this group. Other elements (Ca, Ba, Sr, Se) are associated with carbonates.

- Among the trace elements Se, Li, As, Cs and Sr are much more enriched than ECA and AA. These elements are derived from volcanism continued through the Miocene and related hydrothermal solutions and volatiles as well as clays transported from terrestrial regions.

- It was noticed during the exploitation that $\mathrm{Se}, \mathrm{Li}$, As, Cs and Sr could be produced as byproducts which are important results with regard to economic value of the deposit. However, exploitation of these elements is still neglected.

- There is a great difference between minimum and maximum concentrations indicating that conditions of deposition environment is quite variable, particularly, regarding element input and the amount of material transported varied with respect to climate and volcanic activity. The variation in element concentrations is almost the same in different parts of the deposition environment (three different sampling sites).

- In Krrka deposit, independent behaviour of $\mathrm{B}_{2} \mathrm{O}_{3}$ indicates that boron is not associated with clays and carbonates, and thus, most part of boron must have been derived from volcanic activity (hydrothermal solutions, gases). Based on REE data, high-pH hydrothermal waters also contributed to formation of Kirka borate deposit.

\section{Acknowledgement}

This study was supported by the Scientific Foundation Unit of the Ankara University (Project no. 10B4343004).

\section{References}

Abollino O, Aceto M, Buoso S, Gasparon M, Green W J, Malandrino M and Mentasti E 2004 Distribution of major, minor and trace elements in lake environments of Antarctica; Antarctic Sci. 16(3) 277-291.

Akçay M 2002 Jeokimya Trabzon, Karadeniz Technical University Publications No. 204, 506 (in Turkish).

Akyol E and Akgün F 1990 Palynology of Bigadiç, Kestelek, Emet and Kirka borate-bearing Neogene deposits; MTA Bull. 111 165-173 (in Turkish).

Ataman G and Baysal O 1978 Clay mineralogy of Turkish borate deposits; Chem. Geol. 22 233-247.

Bau M 1991 Rare-earth element mobility during hydrothermal and metamorphic fluid rock interaction and the significance of the oxidation state of europium; Chem. Geol. 93 219-230.

Baysal O 1972 Tunellite, a new hydrous strontium borate from the Sarkkaya borate deposits in Turkey; Bull. Mineral. Res. Explor. Inst. $7922-29$.

Baysal O 1973 Occurrence of Sarıkaya (Kırka) borate deposits, Mining Scientific and Technical Congress, Ankara, pp. 255-277 (in Turkish). 
Baysal O 1974 Preliminary results of investigations on clay minerals of Kırka borate deposits of Turkey; Geol. Bull. Turkey 17 17-30 (in Turkish).

Baysal O and Ataman G 1975 A new borate mineral in Turkey: Discussion on kernite occurrence; Geol. Bull. Turkey 18 3-10 (in Turkish).

Bence A E and Taylor B E 1985 Rare earth element systematics of west Shasta metavolcanic rocks: Petrogenesis and hydrothermal alteration; Econ. Geol. 80 2164-2176.

Boggs S 2009 Petrology of Sedimentary Rocks; Cambridge University Press, Cambridge, England, 600p.

Bürküt Y 1977 Distribution of Li, Rb, Cs and Sr in orthoand para-gneiss and some petrologic results (Istanbul Technical University, Faculty of Mining), 68p (in Turkish).

Constantopoulos J 1988 Fluid inclusion and REE geochemistry of fluorite from south central Idaho; Econ. Geol. 83 626-636.

Ehinola O A, Ejeh O I and Chinyere N 2010 Petrography, microfacies and geochemical characteristics of shallow water carbonates of Nkalagu formation, southeastern Nigeria; Science Focus 15(1) 87-96.

Elkin E M and Margrave J L 1968 Selenium and selenium compounds; In: Kirk Othmer Encyclopedia of Chemical Technology, New York, 17 809-833.

Floyd P A, Helvacı C and Mittwede S K 1998 Geochemical discrimination of volcanic rocks, associated with borate deposits: An exploration tool? J. Geochem. Expl. 60 185205.

Fu X, Wang J, Zeng Y, Tan F and He J 2011 Geochemistry and origin of rare earth elements (REEs) in the Shengli River oilshale, northern Tibet, China; Chemie der Erde 71(1) 21-30.

Halilova H 2004 Biogeochemistry of microelements (I, Zn, $\mathrm{Co}, \mathrm{Mn}, \mathrm{Cu}, \mathrm{Se}$ ), (İlke-Eker Press) 110p (in Turkish).

Helke A 1955 Examination of Turkish mineral deposits II, N. Jb. Min. Abh., pp. 178-180 (in German).

Helvacı C 1983 Mineralogy of the Turkish borate deposits; Geol. Eng. J. 17 37-54 (in Turkish).

Helvacı C 2001 Turkish borate deposits, Chamb. Geol. Eng. Publ., No. 71 (in Turkish).

Helvacı C 2003 Turkish borate deposits: Geological setting: economic importance and boron policy; Balıkesir Univ. Bull. 5(1) 4-41 (in Turkish).

Helvacı C and Alonso R N 2000 Borate deposits of Turkey and Argentina: A summary and geological comparison; Turkish J. Earth Sci. 9 1-27.

Helvacı C and Orti F 2004 Zonning in the Kırka borate deposit, western Turkey: Primary evaporitic fractionation or diagenetic modifications? Canadian Mineral. 42 1179-1204.

Helvacı C, Mordoğan H, Çolak M and Gündoğan İ 2004 Presence and distribution of lithium in borate deposits and some recent lake waters of west-central Turkey; Int. Geol. Rev. 46 177-190.

Henderson P 1984 Rare earth element geochemistry; In: Developments in geochemistry, Elsevier, Amsterdam, pp. 317-347.

Inan K 1975 A model for formation of hydrous borate minerals; Geol. Bull. Turkey 18 165-168 (in Turkish).

Koç Ş, Birey M, Kavrazlı Ö and Koçak İ 2008a Geochemical properties of Kestelek borate deposits and their changes depending on depth and high technological material investigations on borate samples. TÜBITAK project no. 105M356, Ankara, 89p (in Turkish).
Koç Ş, Kavrazlı Ö and Koçak I 2008b Geochemistry of colemanite deposit of Kestelek, Bursa, Turkey; 33rd International Geological Congress, 6-14 August, Oslo, Norway, Abstracts MRB-01 (http://www.cprm.gov.br/ 33IGC/1352424.html).

Koç Ş, Koçak İ and Kavrazlı Ö 2008c Trace elements concentrations of colemanite in Kestelek borate deposit; 16th International symposium on boron, borides and related materials, 7-12 September, Matsue, Shimane, Japan, Abstract, pp. 57-58.

Koçak İ and Koç Ş 2009 Trace element enrichment of Bigadiç borates deposits, Balikesir, Turkiye; Geochem. Cosmochem. Acta 73(13) A671.

Koçak İ and Koç Ş 2011 Trace element contents of Bigadiç and Kestelek borate deposits; 17th International symposium on boron, borides and related materials, 11-17 September, İstanbul, Turkey, p. 232.

Koçak İ and Koç Ş 2012 Major and trace element geochemistry of the Bigadiç borate deposit, Balikesir, Turkey; Geochem. Int. 50(11) 926-951.

Krauskopf K B 1989 Introduction to Geochemistry; McGraw-Hill International Editions, 617p.

McLennan S M 1989 Rare earth elements in sedimantery rocks: Influence of provanance and sedimentary processes, In: Geochemistry and mineralogy of rare earth elements (eds) B R Lipin and G A Mckay, Book Crafters, Michigan, 348p.

Özpeker I 1969 A comparative study of genetic borate deposits in western Anatolia; PhD Thesis, İTÜ AK Press, 116p, İstanbul (in Turkish).

Özpeker I and İnan K 1978 Mineral assemblages in western Anatolian borate deposits and their relations with deposit occurrence; Turkish Geol. Surv. Bull. 21 1-10.

Palmer M R and Helvaci C 1995 The boron isotope geochemistry of the Kirka borate deposit, western Turkey; Geochem. Cosmochem. Acta 59(17) 3599-3605.

Palmer M R and Helvacı C 1997 The boron isotope geochemistry of the Neogene borate deposits of western Turkey; Geochem. Cosmochem. Acta 61(15) 3161-3169.

Şahinci A 1991 Geochemistry of natural waters (Reform Press, Izmir) (in Turkish).

Schroll E 1975 Analytische Geochemie; Ferdinand Enke Verlag, Stuttgart, 292p.

Sunder M 1980 Geochemistry of Sarıkaya (Kırka Eskişehir) borate deposits; Bull. Geol. Soc. Turkey 2 19-34 (in Turkish).

Sverjensky D A 1984 Europium redox equilibria in aqueous solution; Earth Planet. Sci. Lett. 67 70-78.

Taylor S R and McLennan S M 1985 The continental crust: Its composition and evolution; Blackwell, Oxford, 312p.

Weil D F and Drake M J 1973 Europium anomaly in plagioclase feldspar: Experimental results and semi-quantitative model; Science 180 1059-1060.

Yalçın H 1988 Mineralogical-petrographic and geochemical investigation of volcano-sedimentary formations of Kırka (Eskişehir) region; PhD Thesis, Hacettepe University, Institute of Graduate Studies in Science, Beytepe, Ankara, 209p.

Yalçın H and Baysal O 1991 Geological setting, distribution and formation of Kırka (Seyitgazi-Eskişehir) borate deposits; M.T.A Bull. 113 93-104.

Yalçın H, Gündoğdu M N and Liewig N 1989 Relationships between smectite and carbonate minerals in the Kırka volcano sedimentary basin, Eskişehir, Turkey: IXth Intenational Day Conference, Strasbourg, France, Abstract, p. 437. 